University of Nebraska - Lincoln

DigitalCommons@University of Nebraska - Lincoln

\title{
A Greenhouse Gas Emissions Inventory for Nebraska: Livestock and Coal Loom Large
}

Eric R. Holley

Adam Liska

Follow this and additional works at: https://digitalcommons.unl.edu/bseliska

Part of the Atmospheric Sciences Commons, Bioresource and Agricultural Engineering Commons, Climate Commons, Environmental Indicators and Impact Assessment Commons, Natural Resources Management and Policy Commons, Other Civil and Environmental Engineering Commons, Other Earth Sciences Commons, and the Other Environmental Sciences Commons

This Article is brought to you for free and open access by the Biological Systems Engineering at DigitalCommons@University of Nebraska - Lincoln. It has been accepted for inclusion in Adam Liska Papers by an authorized administrator of DigitalCommons@University of Nebraska - Lincoln. 


\title{
A Greenhouse Gas Emissions Inventory for Nebraska: Livestock and Coal Loom Large
}

\author{
Eric R. Holley ${ }^{1}$ and Adam J. Liska ${ }^{2}$ \\ 1 School of Natural Resources, University of Nebraska-Lincoln, Lincoln, NE, USA \\ 2 Department of Biological Systems Engineering \& Department of Agronomy \\ \& Horticulture, University of Nebraska-Lincoln, Lincoln, NE, USA. Email \\ aliska2@unl.edu
}

\begin{abstract}
Mitigation of climate change requires the systematic identification and cataloging of emissions sources at city, state, and national levels. In this study, an inventory of annual greenhouse gas emissions from the state of Nebraska was created based on industry data, and emissions inventories were completed each year from 1990 to 2016. Nebraska's net emissions were found to increase from 56.2 million metric tons of carbon dioxide equivalents $\left(\mathrm{MMtCO}_{2} \mathrm{e}\right)$ in 1990 to $87.4 \mathrm{MMtCO}_{2} \mathrm{e}$ in 2016. Agriculture was found to be the sector with the most emissions $\left(36 \mathrm{MMtCO}_{2} \mathrm{e}\right)$ followed by electricity generation $\left(21 \mathrm{MMtCO}_{2} \mathrm{e}\right)$. In 2016, emissions from beef cattle made up 55\% of agricultural emissions and $23.7 \%$ of net state emissions; if all beef were substituted with pork, net state emissions could be reduced by $17.9 \%$. Coal for electricity had the largest increase in emissions from 1990 to $2016\left(7.4 \mathrm{MMtCO}_{2} \mathrm{e}\right)$ and made up $23.7 \%$ of the state's net emissions in 2016. Net emissions per capita in Nebraska were found to be 46.2 metric tons $\mathrm{CO}_{2}$ e per capita $\left(\mathrm{MtCO}_{2} \mathrm{e}\right)$ in 2015 , which is more than double US average emissions at $18.4 \mathrm{MtCO}_{2} \mathrm{e}$, though potentially similar to those of other agricultural states when emissions from agriculture are included in state inventories.
\end{abstract}

\section{Introduction}

Anthropogenic greenhouse gas (GHG) emissions and associated global climate change will increase the severity and destructiveness of heat waves, droughts, wild- fires, floods, hurricanes, and sea level rise. In the

Published as Chapter 3 in Chittaranjan Ray, Sekhar Muddu, \& Sudhirendar Sharma, editors, Food, Energy, and Water Nexus: A Consideration for the 21st Century. Springer, 2022, pp. 33-66. doi:10.1007/978-3-030-85728-8_3

Copyright (C) 2022 Springer Nature Switzerland AG. Used by permission. 
USA, these impacts are expected to cost hundreds of billions of dollars annually by the end of the century if global GHG emissions are not substantially reduced (USGCRP 2018). The cumulative economic effect of climate change from 2020 to 2300 has been estimated to be between $\$ 1,390$ under current proposed levels of mitigation and \$2,197 trillion dollars for business as usual (Yumashev et al. 2019). Climate change impacts and economic losses could also increase significantly by compounding feedback effects from the melting of Arctic permafrost and other cryosphere elements, meaning projections probably underestimate costs (Yumashev et al. 2019). Over the next two decades, actions to reduce anthropogenic GHG emissions have the potential to limit atmospheric temperature increases to only $2{ }^{\circ} \mathrm{C}$ above the pre-industrial era, but extensive emissions mitigation must occur on an economy-wide and global scale (UNEP 2017; Figueres et al. 2017; Millar et al. 2017; Xu and Ramanathan 2017). As industrial-scale carbon sequestration technologies ("negative carbon emissions") are expected to cost many trillions of dollars to implement (Hansen et al. 2017), and as other potential solutions (e.g., geoengineering solar radiation) are excessively risky (Morton 2016), the only practical and immediate approach to mitigate climate change is to reduce the annual rate of global anthropogenic GHG emissions alongside increased natural and, potentially, man-made carbon sequestration systems. Ultimately, a preponderance of high-emitting countries must reduce their emissions to limit increases in atmospheric $\mathrm{CO}_{2}$ concentrations. This will probably occur with a binding international climate change agreement, which has yet to come to fruition. Even without such an agreement, many countries have set targets for emissions reductions and have begun transitions to low-carbon economies.

The first stage of emissions reduction requires identification of GHG emissions rates and their sources. While many country-level GHG emissions have been quantified since the signing of the Kyoto Protocol, based on data such as national aggregate energy use, GHG emissions inventories for subnational regions (states, provinces, etc.) have been far less developed. Subnational inventories can be key tools for mitigating emissions because local characteristics and associated GHG emissions reduction potentials vary. Regional socio-economic differences in fossil fuel production and use, in electricity generation, transportation, industry, forestry, and agriculture, can present more specific and actionable GHG emissions reduction strategies. 
Agricultural regions can have particularly high GHG emissions because (1) they can disrupt large amounts of carbon stored in soils, perennial plants, and forests; (2) livestock and rice are significant sources of methane $\left(\mathrm{CH}_{4}\right)$ emissions, which has a global warming potential 25 times more potent than $\mathrm{CO}_{2}$, (3) nitrogen fertilizer and manure use produce nitrous oxide $\left(\mathrm{N}_{2} \mathrm{O}\right)$, which has a global warming potential 298 times more potent than $\mathrm{CO}_{2}$, (4) the scale of agricultural systems needed to produce current food use amplifies inefficiencies and their resulting GHG emissions; and (5) agricultural regions generally export a high proportion of output to meet demand of other areas. As one of the leading agricultural economies and exporters of the USA, the state of Nebraska has many characteristics of an agricultural region with potentially high GHG emissions. In 2018, Nebraska had the highest state-level commercial red meat production, highest beef exports among states, and the largest number of cattle on feed (NDA 2019). The state is also the third largest producer of maize for grain in the USA, according to state statistics. In 2012, the livestock industry in Nebraska had annual sales of roughly $\$ 11.7$ billion dollars (USDA NASS 2019). Nebraska also has the largest area under irrigation among states in the USA, which requires substantial amounts of energy (USDA ERS 2012). In 2017, Nebraska had 47,400 farms and ranches with an average size of 386 hectares and a total of 18.3 million hectares of agricultural land (NDA 2019). In 2017, Nebraska ranked second in maize-ethanol production capacity, with 25 operating biorefineries that have a production capacity of $\sim 7.6$ billion liters and utilize $\sim 40 \%$ of the state's maize crop.

Livestock production is a significant source of GHG emissions. Livestock farming contributes $\sim 14.5 \%$ of anthropogenic GHG emissions globally, although estimates vary (Gerber et al. 2013). A large portion of GHG emissions from livestock come from enteric fermentation, the digestive process in ruminant animals such as cattle, sheep, or goats. Due to their large population and size, cattle account for a majority of GHG emissions from enteric fermentation (ICF 2004). Around 65\% of global livestock-related GHG emissions are from cattle, and over $80 \%$ of livestock-related GHG emissions are from ruminants (Gerber et al. 2013). The effect of livestock on agricultural soils also plays a large role in emissions, through the spread of manure on fields and pastures and the leeching and runoff of nitrogen from manure into soil and water systems. Manure use and management from livestock accounts for $26 \%$ of 
global livestock-related emissions (Gerber et al. 2013). To reduce GHG emissions in Nebraska, significant attention will need to be paid to livestock and livestock management.

A second significant source of emissions comes from electricity generation. Emissions of GHGs from electricity generation accounted for 28\% of total emissions for the USA in 2016 (EPA 2019). Electricity-related GHG emissions in Nebraska largely come from the fuel source in the generation of electricity, specifically coal-powered plants. Generation of electricity is dependent on demand for electricity that is in turn dependent upon economic growth, relative energy prices, technological efficiency, and several other factors (EIA 2014). If economic growth and energy demand continues to increase and relevant energy prices remain stable, electricity generation will need to either increase the efficiency of current technologies (which may already be at or near efficiency limits) or switch to zero or net-zero emissions sources for energy (e.g., renewables, nuclear, carbon-capture systems) to maintain or reduce GHG emissions. Addressing GHG emissions from electricity generation is vital to reducing Nebraska's contribution to climate change.

Emissions inventories of GHGs are precursors for action. They allow comprehensive knowledge of a system and its emissions. Emissions inventories are a building block upon which solutions can be tailored to reduce or even eliminate emissions dependent on the characteristics of the system. Regulation (e.g., cap-and-trade, carbon tax), market solutions (e.g., investments, incorporation of emissions costs into business plans and stock prices), and risk management systems (e.g., insurance, FEMA) all rely on inventories to provide a basis for resource allocation and management. State-specific inventories allow a more accurate and relevant analysis of state emissions compared to federal inventories and provide a framework for state-relevant solutions to climate change. Prior to this analysis, a state-specific GHG emissions inventory for Nebraska was inaccessible. While default EPA model inputs could be used to estimate comprehensive GHG emissions for Nebraska, data were never coalesced into a publicly available report, as provided here, nor has an analysis and comparison of the relevant systems been presented. This inventory uses non-default data where data were accessible: fossil fuel combustion, natural gas transmission and distribution, transportation (non-highway), and emissions from fires (2000-2016). Future national GHG emissions inventories would benefit from the continuous evaluation of state-level emissions by governmental or nongovernmental organizations. 


\section{Methods for Estimation of Greenhouse Gas Emissions}

Emissions were estimated using the most recent version of the US Environmental Protection Agency's (EPA) State Greenhouse Gas Inventory Tool (SIT) (downloaded December 1, 2019) using data specific for Nebraska where available (data sources detailed below). The calculation methods in the SIT are based on the August 2004 version of EPA's Emission Inventory Improvement Program guidance for GHGs (ICF 2004). Default input values in the SIT were collected from relevant government or industry sources for each sector (i.e., US Geological Survey, Energy Information Administration, Nebraska Energy Office); details of the SIT's calculation methods are available in the SIT User Guide (EPA 2019). The individual modules for each sector in the SIT are Excel workbooks populated with default emission factors (EFs) and state-specific input values. Conversions from one unit to another were used in all calculations where appropriate. Emissions were calculated using available data for 26 years from 1990 to 2016 to keep annual comparisons as accurate as possible while still providing enough data to observe trends. The SIT estimates GHG emissions in million metric tons of $\mathrm{CO}_{2}$ equivalent $\left(\mathrm{MMtCO}_{2} \mathrm{e}\right)$ from eight major source sectors: agriculture, fossil fuel combustion, industrial processes, natural gas transmission and distribution, transportation, solid waste, wastewater treatment, and land use, land use change, and forestry (LULUCF). The global warming potentials (GWP) used for each GHG were $1\left(\mathrm{CO}_{2}\right), 25\left(\mathrm{CH}_{4}\right), 298\left(\mathrm{~N}_{2} \mathrm{O}\right), 14,800$ (HFC-23), and 22,800 ( $\left.\mathrm{SF}_{6}\right)$.

Emissions of GHGs from agriculture were calculated using the agriculture module of the EPA's SIT. The agriculture module calculates emissions for nine categories: enteric fermentation $\left(\mathrm{CH}_{4}\right)$, manure management $\left(\mathrm{CH}_{4}\right.$ and $\left.\mathrm{N}_{2} \mathrm{O}\right)$, residues and legumes from agricultural soils $\left(\mathrm{N}_{2} \mathrm{O}\right)$, fertilizers applied to agricultural soils $\left(\mathrm{N}_{2} \mathrm{O}\right)$, manure on agricultural soils $\left(\mathrm{N}_{2} \mathrm{O}\right)$, liming of agricultural soils $\left(\mathrm{CO}_{2}\right)$, urea fertilization $\left(\mathrm{CO}_{2}\right)$ (fertilizer production), rice cultivation $\left(\mathrm{CH}_{4}\right)$, and burning of agricultural residues $\left(\mathrm{CH}_{4}\right)$. Rice cultivation and burning of agricultural residues were not included in this inventory as these are not practices that take place in Nebraska. Emissions from livestock were based on animal populations from the USDA's Quick Stats tool (USDA NASS 2018) and corresponding annual EFs ( $\mathrm{kg} \mathrm{CH}$ per head per year) from the SIT. These livestock categories, with enteric fermentation EFs where appropriate, include the following: dairy cows (108.9-139.7), dairy replacement 
heifers (42.2-68.7), beef cows (86.5-92.01), beef replacement heifers (52.4-67.6), heifer stockers (50.4-58.9), steer stockers (53.1-56.9), bulls (88.3-95.1), feedlot heifers (37.2-43.4), feedlot steers (36.3-42.2), calves, breeding swine (1.5), market swine (four categories by weight; 1.5), layer chickens, broiler chickens, sheep (8), goats (5), and horses (18). Emissions from legumes and residues were estimated based on annual production of alfalfa, maize for grain, wheat, barley, sorghum for grain, oats, rye, millet, and soybeans (USDA NASS 2018). Liming of agricultural soils is calculated by multiplying the total limestone or dolomite applied to soil by an EF (Mt C per Mt limestone or dolomite). Urea fertilization is calculated by multiplying total urea applied to soil by an EF (Mt C per Mt urea).

Historic (pre-1990) agricultural GHG emissions for Nebraska are estimated from historic cattle head counts and assumed EFs. Total cattle head count for Nebraska between 1920 and 2016 includes dairy cows, beef cows, stockers, calves, and bulls. Feedlot cattle data starts in 1965 for Nebraska (USDA NASS 2018) so feedlot totals for years 1920-1964 were assumed to be the value for 1965 . This assumption means pre1965 values are slightly inflated and actual headcount was likely lower. Historic values were obtained by taking historic cattle head counts (USDA NASS 2018) multiplied by the EF from 1990 (earliest calculated $\mathrm{EF}$ in the SIT) to give values in kilograms of methane. These values were converted to $\mathrm{MMtCO}_{2}$ e to give historic emissions from enteric fermentation. Enteric fermentation accounts for $47.7 \%$ on average of total agricultural emissions from 1990 to 2016 so values were divided by 0.477 to give historic agricultural emissions in $\mathrm{MMtCO}_{2} \mathrm{e}$.

Emissions of GHGs from fossil fuel combustion were calculated in two main categories: residential, commercial, and industrial (RCI) emissions and electricity generation from power plants. Emissions of GHGs for RCI were calculated using two SIT modules: $\mathrm{CO}_{2} \mathrm{FFC}$ for $\mathrm{CO}_{2}$ emissions and the stationary combustion module for $\mathrm{CH}_{4}$ and $\mathrm{N}_{2} \mathrm{O}$ emissions (ICF 2004). Residential $\mathrm{CO}_{2}$ emissions are calculated by multiplying consumption (billion BTUs) of a fuel type by the corresponding EF (kg C per million BTUs) for the following types: coal, distillate fuel, kerosene, liquefied petroleum gas (LPG), and natural gas. Commercial $\mathrm{CO}_{2}$ emissions are calculated the same as residential emissions with the addition of two categories: motor gasoline and residual fuel. Industrial $\mathrm{CO}_{2}$ emissions are calculated by multiplying total energy consumption (billion BTUs) 
minus the result of non-energy-related material consumption (billion BTUs) multiplied by a storage factor percentage, which yields net-combustible consumption (billion BTUs). The net combustible consumption is then multiplied by an EF ( $\mathrm{kg} \mathrm{C}$ per million BTUs) for the following categories: coking coal, other coal, asphalt and road oil, aviation gasoline blending components, crude oil, distillate fuel, naphtha less than $401^{\circ} \mathrm{F}$ feedstocks, other oils greater than $401^{\circ} \mathrm{F}$ feedstocks, kerosene, LPG, lubricants, motor gasoline, motor gasoline blending components, miscellaneous petroleum products, petroleum coke, pentanes plus, residual fuel, still gas, special naphthas, unfinished oils, waxes, and natural gas. While transportation and bunker fuels are included in the $\mathrm{CO}_{2} \mathrm{FFC}$ module, transportation emissions from mobile sources are included in the transportation sector and bunker fuel data were not available for $\mathrm{Ne}$ braska. Emissions of $\mathrm{N}_{2} \mathrm{O}$ and $\mathrm{CH}_{4}$ in the RCI module are calculated by multiplying energy consumption (billion BTUs) by corresponding EFs (metric tons of $\mathrm{N}_{2} \mathrm{O}$ per billion BTUs and metric tons of $\mathrm{CH}_{4}$ per billion BTUs) in the same manner as $\mathrm{CO}_{2}$ emissions with the addition of wood as a category. Emissions from electricity generation were calculated using fuel consumption data for Nebraska available from the Energy Information Administration (EIA 2018a, b). While more site-specific emissions data are available from 2010 onward (EPA 2019), the SIT was used to calculate emissions to provide a consistent calculation for comparisons from 1990 to 2015. Consumption data (billion BTUs) for electricity generation is multiplied by the relevant EF for each fuel type, with factors and fuel types the same as residential for $\mathrm{CO}_{2}, \mathrm{~N}_{2} \mathrm{O}$, and $\mathrm{CH}_{4}$ emissions.

The industrial processes module calculates emissions based on the amount of material produced in the state (ICF 2004). In Nebraska, several categories were not included because the material is either not produced in the state or production data are unavailable: dolomite, magnesium, aluminum, nitric acid, adipic acid, and hcfc-22. Default production values for Nebraska present in the SIT were used for all other materials. Industrial processes emissions were calculated by multiplying production values by an EF (metric tons $\mathrm{CO}_{2}$ emitted per metric ton of material produced) for the following materials: clinker cement, cement kiln dust, high-calcium lime, dolomitic lime, limestone, soda ash consumption, iron and steel production (basic oxygen furnace with coke ovens), iron and steel production (basic oxygen furnace without coke ovens), iron and steel production (electric arc furnace), ammonia production, 
urea production, and electric power transmission and distribution. Lime is further multiplied by a $\mathrm{CO}_{2}$ reabsorption factor (0.8) that accounts for the precipitation of calcium carbonate during the process. Ozone-depleting substance (ODS) substitutes are calculated by multiplying national ODS emissions $\left(\mathrm{MtCO}_{2} \mathrm{e}\right)$ by state population divided by national population for Nebraska's share of national emissions.

Emissions for natural gas transmission and distribution were calculated using the natural gas (NG) and oil systems module in the SIT. The emissions are broken down into five categories: NG production, NG transmission, NG distribution, NG venting/flaring, and petroleum systems. Default values from the SIT are used for the number of NG wells in Nebraska, number of gas transmission and storage compressor stations, and oil production. NG transmission and distribution were calculated using miles of pipeline and services (DOT 2018). Production of NG is calculated by multiplying the total number of wells by an EF (metric tons $\mathrm{CH}_{4}$ per year per activity unit) which varies annually. Emissions from NG transmission were calculated by multiplying an $\mathrm{EF}$ (metric tons $\mathrm{CH}_{4}$ per year per activity unit) by each input value: miles of transmission pipeline, number of gas transmission compressor stations, and number of gas storage compressor stations. Emissions from NG distribution were calculated by multiplying an $\mathrm{EF}$ (metric tons $\mathrm{CH}_{4}$ per year per activity unit) by each input value: miles of cast iron distribution pipeline, miles of unprotected steel distribution pipeline, miles of protected steel distribution pipeline, mile of plastic distribution pipeline, total number of services, number of unprotected steel services, and the number of protected steel services. Emissions from NG venting/flaring were calculated by multiplying the total $\mathrm{NG}$ vented or flared in the state (billion BTUs) by an EF (metric tons $\mathrm{CO}_{2}$ per year billion BTU). Petroleum systems were calculated by multiplying amount of oil in production, refining, and transportation in the state (per 1000 barrels) by an EF $\left(\mathrm{kg} \mathrm{CH}_{4}\right.$ per year per 1000 barrels).

The transportation section of the SIT includes both highway and nonhighway (e.g., aviation, marine vessels, locomotives, and tractors) vehicles. Default vehicle miles traveled (VMT) were used to calculate emissions for highway vehicles (FHWA 2019), and petroleum consumption values were used for non-highway vehicles (EIA 2019a). Highway vehicle $\mathrm{N}_{2} \mathrm{O}$ and $\mathrm{CH}_{4}$ emissions were calculated by multiplying VMT by an $\mathrm{EF}$ for each type of vehicle and emissions control technology and then 
distributed by vehicle age. The types of vehicles are light-duty gas vehicles (LDGV), light-duty gasoline trucks (LDGT), heavy-duty gas vehicles (HDGV), light-duty diesel vehicles (LDDV), light-duty diesel trucks (LDDT), heavy-duty diesel vehicles (HDDV), and motorcycles (MC). Emissions control technologies are as follows: T2 three-way catalysts, T1 three-way catalysts, T0 early three-way, oxidation catalysts, non-catalysts, low emission vehicles, advanced, moderate, and uncontrolled. Nonhighway $\mathrm{N}_{2} \mathrm{O}$ and $\mathrm{CH}_{4}$ emissions were calculated by multiplying fuel consumption by a density factor (kg/L) and by relevant EFs (g GHG per kg fuel, $\mathrm{N}_{2} \mathrm{O}$, and $\mathrm{CH}_{4}$ ) for aviation, boats, locomotives, and other (includes farm equipment, construction equipment, industrial, and snowmobiles). Carbon dioxide emissions in the transportation sector are calculated by the $\mathrm{CO}_{2} \mathrm{FFC}$ module of the SIT and used instead of $\mathrm{CO}_{2}$ emissions calculated using VMT in the transportation module because the method used in the $\mathrm{CO}_{2} \mathrm{FFC}$ module is less uncertain (ICF 2004). Transportation emissions are calculated by multiplying fuel consumption (billion BTUs) by an EF (kg C per million BTUs) for each of the following categories: aviation gasoline, distillate fuel, jet fuel kerosene, jet fuel naphtha, LPG, motor gasoline, residual fuel, and natural gas.

The solid waste module uses annual tons of solid waste landfilled and population as inputs to calculate emissions for municipal solid waste (MSW) landfills, minus any methane emissions flared. Default values present in the SIT were used to calculate emissions. Combustion of municipal solid waste was not calculated for Nebraska due to lack of available data. Methane emissions from MSW landfills were calculated using a first-order decay model from the SIT $\left(Q_{t x}=A * k^{*} R_{x} * L_{0} * e^{-k(T-x)}\right)$ where $Q_{t x}$ is the amount of $\mathrm{CH}_{4}$ generated in a particular year, $A$ is the normalization factor $\left(1-\mathrm{e}^{\mathrm{k}}\right) / \mathrm{k}, \mathrm{k}$ is the $\mathrm{CH}_{4}$ generation rate per year, $\mathrm{R}_{\mathrm{x}}$ is the amount of waste landfilled for a particular year, $\mathrm{L}_{0}$ is the $\mathrm{CH}_{4}$ generation potential ( $\mathrm{m}^{3} / \mathrm{Mt}$ of refuse), $\mathrm{T}$ is the current year (i.e., 2019), and $\mathrm{x}$ is the year the waste was input into the system.

The wastewater module of the SIT calculates emissions for both municipal and industrial wastewater. Emissions from municipal wastewater are calculated using state population values multiplied by a series of EFs to generate the amount of $\mathrm{CH}_{4}$ produced per metric ton. This process does not account for collected $\mathrm{CH}_{4}$ and assumes all $\mathrm{CH}_{4}$ is released to the atmosphere. Industrial wastewater emissions are calculated by red meat production in the state. The SIT assumes a constant amount 
of emissions per metric ton of meat processed at meat processing facilities and deals only with the wastewater at those facilities. Municipal $\mathrm{CH}_{4}$ emissions from wastewater are calculated by multiplying state population by per capita 5-day biochemical oxygen demand $\left(\mathrm{BOD}_{5}, 0.09\right)$, the number of days in a year, an $\mathrm{EF}\left(0.6 \mathrm{Gg} \mathrm{CH}_{4}\right.$ per $\mathrm{Gg} \mathrm{BOD}$ ), and then the percentage of wastewater $\mathrm{BOD}_{5}$ that is anaerobically digested. Direct wastewater $\mathrm{N}_{2} \mathrm{O}$ emissions are calculated by multiplying population by the fraction of the population not on septic by an EF $\left(\mathrm{g} \mathrm{N}_{2} \mathrm{O}\right.$ per person per year). Indirect wastewater $\mathrm{N}_{2} \mathrm{O}$ emissions are calculated by multiplying population by the total annual protein consumption, the fraction of nitrogen content in protein, and the fraction of non-consumed nitrogen, minus the direct nitrogen emissions from wastewater, multiplied by the percentage of biosolids not used as fertilizer, and an EF $\left(\mathrm{kg} \mathrm{N}_{2} \mathrm{O}-\mathrm{N}\right.$ per $\mathrm{kg}$ sewage $\mathrm{N}$-produced). Industrial wastewater from red meat production is calculated by multiplying metric tons of production by wastewater outflow ( $\mathrm{m}^{3}$ per metric ton), chemical oxygen demand (COD), an EF ( $\mathrm{g} \mathrm{CH}_{4}$ per $\mathrm{g} \mathrm{COD}$ ), and the fraction of COD degraded.

The LULUCF module is composed of seven categories: settlement soils, urban trees, burning $\mathrm{CH}_{4}$, burning $\mathrm{N}_{2} \mathrm{O}$, yard trimmings, forest carbon flux, and agricultural soil carbon flux. Default SIT values were used for all categories except for burning $\mathrm{CH}_{4}$ and burning $\mathrm{N}_{2} \mathrm{O}$ from 2000 to 2016. Data provided by the Nebraska Forest Service was used to calculate emissions from 2000 to 2016; data before 2000 was not available. Settlement soils are calculated by multiplying total synthetic fertilizer applied to settlements (Mt N) by an EF and the molecular weight ratio $\left(\mathrm{N}_{2} \mathrm{O} / \mathrm{N}_{2}\right)$. Urban trees are calculated by multiplying total urban area $\left(\mathrm{km}^{2}\right)$ by the fraction of urban area with tree cover and a carbon sequestration factor (Mt $\mathrm{C}$ per hectare per year). Burning $\mathrm{CH}_{4}$ and $\mathrm{N}_{2} \mathrm{O}$ were calculated by multiplying the area burned (ha) by the average biomass density for forests (kg dry matter per ha), the combustion efficiency for the type of forest, and an EF (g/kg dry matter burned). Yard trimmings were calculated by multiplying default assumed percentages of grass, leaves, and branches applied to the total landfilled yard trimmings and scraps by wet weight (state population multiplied by the national landfilled yard trimmings and food scraps per capita). Then, the amount of carbon for each category added to landfills annually is calculated by multiplying the landfilled materials wet weight by the initial carbon content percentage for grass, leaves, branches, and food scraps 
and by the dry-to-wet weight ratio for each category to get total mass additions ( $\mathrm{Gg} \mathrm{C}$ ). The total annual stocks of landfilled carbon are then calculated by summing the carbon remaining from all previous years' deposits of waste. The stock of carbon remaining in landfills for any given year is calculated as follows: total mass additions multiplied by a term (percentage of $\mathrm{C}$ stored permanently + (1 - percentage of $\mathrm{C}$ stored permanently) multiplied by $\mathrm{e}^{\wedge}(-\ln (0.5) /$ half-life of degradable $\left.C)\right)$. The annual flux of carbon stored in landfills is then calculated by subtracting the current year's carbon stocks from the previous year's stocks. Forest carbon flux is calculated by multiplying outputs of the Carbon Calculation Tool (CCT) from the USDA Forest Service for carbon storage (million metric tons of carbon) and calculating the change in carbon storage over an inventory year. This change is then converted to $\mathrm{MMtCO}_{2} \mathrm{e}$ to give net sequestration or emissions from aboveground biomass, belowground biomass, dead wood, litter, and soil organic carbon. Carbon storage from wood products and landfills is calculated by multiplying estimates of harvested wood stocks from 1987, 1992, and 1997 and averaging change from 1987 to 1992 and 1992 to 997 to get average annual change for each of those ranges. The average annual change for 19982016 is assumed to be the average annual change for 1992-1997. The average annual change was added to the net sequestration or emissions from the other categories to give total annual net sequestration or emission or forest carbon flux. Agricultural soil flux is calculated in much the same way as forest carbon flux, but without wood products and landfills, for cropland remaining cropland, land converted to cropland, grassland remaining grassland, and land converted to grassland (EPA 2019).

\section{A Greenhouse Gas Emissions Inventory for Nebraska}

\subsection{Aggregate State Emissions 1990-2016}

Nebraska's net emissions increased from 56.2 $\mathrm{MMtCO}_{2} \mathrm{e}$ in 1990 to 87.4 $\mathrm{MMtCO}_{2} \mathrm{e}$ in 2016 with an average increase of $1.2 \mathrm{MMtCO}_{2}$ e per year (Tables 1 \& 2). For comparison, Iowa and Illinois (both comprehensive inventories) reported 131.8 and 119.8 $\mathrm{MMtCO}_{2} \mathrm{e}$, respectively, in 2015 for total emissions which include non-energy sectors such as agriculture (Iowa DNR 2018; ICF 2018). Kansas, Texas, and Minnesota reported 63.1, 
Table 1 Emissions per capita for Nebraska and the USA in metric tons (MtCO2e)

\begin{tabular}{lrrrr} 
Category & 1990 & 2016 & Change & \% Change \\
\hline Nebraska population & $1,578,385$ & $1,893,765$ & 315,380 & 20 \\
US population & $249,620,000$ & $321,040,000$ & $71,420,000$ & 29 \\
Nebraska net emissions, $\mathrm{MMtCO}_{2} \mathrm{e}$ & 56.2 & 87.4 & 31.2 & 56 \\
US net emissions, $\mathrm{MMtCO}_{2} \mathrm{e}$ & 5564 & 5913 & 349 & 6 \\
Fraction NE of US population & 0.006 & 0.006 & - & -7 \\
Nebraska per capita emissions, $\mathrm{MtCO}_{2} \mathrm{e}$ & 35.6 & 46.2 & 10.6 & 30 \\
US per capita emissions, $\mathrm{MtCO}_{2} \mathrm{e}$ & 22.3 & 18.4 & -3.9 & -17 \\
\hline
\end{tabular}

Sources: Nebraska Energy Office; United Nations Population Division (2018), U.S. Census Bureau (2018), EPA (2019)

Table 2 Inventory of GHG emissions from Nebraska by sector $\left(\mathrm{MMtCO}_{2} \mathrm{e}\right), 1990-2016$

\begin{tabular}{|c|c|c|c|c|c|c|c|}
\hline Emissions $\left(\mathrm{MMtCO}_{2} e\right)$ & 1990 & 1995 & 2000 & 2005 & 2010 & 2015 & 2016 \\
\hline Agriculture & 27.85 & 28.84 & 33.09 & 32.94 & 35.35 & 36.79 & 36.01 \\
\hline Enteric fermentation & 9.91 & 11.15 & 13.04 & 12.74 & 13.06 & 13.03 & 13.38 \\
\hline Manure management & 2.55 & 2.45 & 2.88 & 2.54 & 2.75 & 2.84 & 2.90 \\
\hline Ag soils & 15.26 & 15.10 & 16.35 & 17.53 & 19.34 & 20.74 & 19.55 \\
\hline Liming & 0.08 & 0.09 & 0.11 & 0.03 & 0.10 & 0.04 & 0.04 \\
\hline Urea fertilization & 0.04 & 0.05 & 0.07 & 0.09 & 0.10 & 0.13 & 0.13 \\
\hline Agricultural residue burning & 0.00 & 0.00 & 0.01 & 0.01 & 0.01 & 0.01 & 0.01 \\
\hline Power plants & 13.53 & 16.94 & 19.00 & 21.19 & 22.94 & 23.27 & 21.04 \\
\hline Electric power $\left(\mathrm{CO}_{2}\right)$ & 13.47 & 16.86 & 18.90 & 21.08 & 22.83 & 23.15 & 20.93 \\
\hline Coal & 13.26 & 16.67 & 18.55 & 20.63 & 22.59 & 22.90 & 20.60 \\
\hline Petroleum & 0.01 & 0.03 & 0.05 & 0.03 & 0.02 & 0.01 & 0.01 \\
\hline Natural gas & 0.19 & 0.16 & 0.30 & 0.43 & 0.21 & 0.24 & 0.33 \\
\hline Electric power $\left(\mathrm{CH}_{4}\right)$ & 0.00 & 0.00 & 0.01 & 0.01 & 0.01 & 0.01 & 0.01 \\
\hline Coal & 0.00 & 0.00 & 0.00 & 0.01 & 0.01 & 0.01 & 0.01 \\
\hline Petroleum & 0.00 & 0.00 & 0.00 & 0.00 & 0.00 & 0.00 & 0.00 \\
\hline Natural gas & 0.00 & 0.00 & 0.00 & 0.00 & 0.00 & 0.00 & 0.00 \\
\hline Wood & - & - & - & - & - & - & - \\
\hline Electric power $\left(\mathrm{N}_{2} \mathrm{O}\right)$ & 0.06 & 0.08 & 0.09 & 0.10 & 0.11 & 0.11 & 0.10 \\
\hline Coal & 0.06 & 0.08 & 0.09 & 0.10 & 0.11 & 0.11 & 0.10 \\
\hline Petroleum & 0.00 & 0.00 & 0.00 & 0.00 & 0.00 & 0.00 & 0.00 \\
\hline Natural gas & 0.00 & 0.00 & 0.00 & 0.00 & 0.00 & 0.00 & 0.00 \\
\hline Wood & - & - & - & - & - & - & - \\
\hline RCI & 9.02 & 10.46 & 10.25 & 10.06 & 12.41 & 13.42 & 13.45 \\
\hline Residential $\left(\mathrm{CO}_{2}\right)$ & 2.51 & 2.69 & 2.77 & 2.51 & 2.67 & 2.34 & 2.20 \\
\hline Coal & 0.00 & 0.00 & - & 0.00 & - & - & - \\
\hline Petroleum & 0.34 & 0.34 & 0.50 & 0.48 & 0.53 & 0.39 & 0.35 \\
\hline Natural gas & 2.17 & 2.34 & 2.27 & 2.03 & 2.14 & 1.94 & 1.86 \\
\hline Residential $\left(\mathrm{CH}_{4}\right)$ & 0.03 & 0.03 & 0.03 & 0.02 & 0.02 & 0.02 & 0.02 \\
\hline Coal & 0.00 & 0.00 & - & 0.00 & - & - & - \\
\hline Petroleum & 0.00 & 0.00 & 0.00 & 0.00 & 0.00 & 0.00 & 0.00 \\
\hline Natural gas & 0.00 & 0.01 & 0.01 & 0.00 & 0.00 & 0.00 & 0.00 \\
\hline Wood & 0.03 & 0.03 & 0.02 & 0.02 & 0.02 & 0.02 & 0.01 \\
\hline
\end{tabular}


Table 2 Inventory of GHG emissions from Nebraska by sector $\left(\mathrm{MMtCO}_{2} \mathrm{e}\right), 1990-2016$ (continued)

\begin{tabular}{|c|c|c|c|c|c|c|c|}
\hline Emissions $\left(\mathrm{MMtCO}_{2} e\right)$ & 1990 & 1995 & 2000 & 2005 & 2010 & 2015 & 2016 \\
\hline Residential $\left(\mathrm{N}_{2} \mathrm{O}\right)$ & 0.01 & 0.01 & 0.01 & 0.00 & 0.01 & 0.00 & 0.00 \\
\hline Coal & 0.00 & 0.00 & - & 0.00 & - & - & - \\
\hline Petroleum & 0.00 & 0.00 & 0.00 & 0.00 & 0.00 & 0.00 & 0.00 \\
\hline Natural gas & 0.00 & 0.00 & 0.00 & 0.00 & 0.00 & 0.00 & 0.00 \\
\hline Wood & 0.00 & 0.00 & 0.00 & 0.00 & 0.00 & 0.00 & 0.00 \\
\hline Commercial $\left(\mathrm{CO}_{2}\right)$ & 2.13 & 2.20 & 1.77 & 1.62 & 1.86 & 1.96 & 1.82 \\
\hline Coal & 0.01 & 0.02 & - & 0.01 & - & - & - \\
\hline Petroleum & 0.22 & 0.10 & 0.23 & 0.15 & 0.16 & 0.30 & 0.30 \\
\hline Natural gas & 1.90 & 2.08 & 1.54 & 1.47 & 1.70 & 1.65 & 1.52 \\
\hline Commercial $\left(\mathrm{CH}_{4}\right)$ & 0.01 & 0.01 & 0.01 & 0.01 & 0.01 & 0.01 & 0.01 \\
\hline Coal & 0.00 & 0.00 & - & 0.00 & - & - & - \\
\hline Petroleum & 0.00 & 0.00 & 0.00 & 0.00 & 0.00 & 0.00 & 0.00 \\
\hline Natural gas & 0.00 & 0.00 & 0.00 & 0.00 & 0.00 & 0.00 & 0.00 \\
\hline Wood & 0.00 & 0.00 & 0.00 & 0.00 & 0.00 & 0.00 & 0.00 \\
\hline Commercial $\left(\mathrm{N}_{2} \mathrm{O}\right)$ & 0.00 & 0.00 & 0.00 & 0.00 & 0.00 & 0.00 & 0.00 \\
\hline Coal & 0.00 & 0.00 & - & 0.00 & - & - & - \\
\hline Petroleum & 0.00 & 0.00 & 0.00 & 0.00 & 0.00 & 0.00 & 0.00 \\
\hline Natural gas & 0.00 & 0.00 & 0.00 & 0.00 & 0.00 & 0.00 & 0.00 \\
\hline Wood & 0.00 & 0.00 & 0.00 & 0.00 & 0.00 & 0.00 & 0.00 \\
\hline Industrial $\left(\mathrm{CO}_{2}\right)$ & 4.32 & 5.51 & 5.65 & 5.87 & 7.82 & 9.06 & 9.38 \\
\hline Coal & 0.21 & 0.63 & 0.76 & 0.74 & 1.21 & 2.01 & 1.90 \\
\hline Petroleum & 2.79 & 2.60 & 2.46 & 2.96 & 2.16 & 2.35 & 2.46 \\
\hline Natural gas & 1.32 & 2.28 & 2.43 & 2.16 & 4.45 & 4.71 & 5.02 \\
\hline Industrial $\left(\mathrm{CH}_{4}\right)$ & 0.00 & 0.01 & 0.01 & 0.01 & 0.01 & 0.01 & 0.01 \\
\hline Coal & 0.00 & 0.00 & 0.00 & 0.00 & 0.00 & 0.01 & 0.00 \\
\hline Petroleum & 0.00 & 0.00 & 0.00 & 0.00 & 0.00 & 0.00 & 0.00 \\
\hline Natural gas & 0.00 & 0.00 & 0.00 & 0.00 & 0.00 & 0.00 & 0.00 \\
\hline Wood & - & 0.00 & 0.00 & 0.00 & 0.00 & 0.00 & 0.00 \\
\hline Industrial $\left(\mathrm{N}_{2} \mathrm{O}\right)$ & 0.01 & 0.01 & 0.01 & 0.01 & 0.02 & 0.02 & 0.02 \\
\hline Coal & 0.00 & 0.00 & 0.00 & 0.00 & 0.01 & 0.01 & 0.01 \\
\hline Petroleum & 0.01 & 0.01 & 0.01 & 0.01 & 0.01 & 0.01 & 0.01 \\
\hline Natural gas & 0.00 & 0.00 & 0.00 & 0.00 & 0.00 & 0.00 & 0.00 \\
\hline Wood & - & 0.00 & 0.00 & 0.00 & 0.00 & 0.00 & 0.00 \\
\hline Industrial processes & 0.99 & 1.47 & 2.13 & 2.12 & 1.94 & 2.19 & 2.23 \\
\hline $\mathrm{CO}_{2}$ emissions & 0.83 & 1.14 & 1.56 & 1.45 & 1.06 & 1.24 & 1.26 \\
\hline Cement manufacture & 0.32 & 0.60 & 0.69 & 0.71 & 0.41 & 0.52 & 0.52 \\
\hline Lime manufacture & - & 0.07 & 0.06 & 0.09 & 0.09 & 0.11 & 0.11 \\
\hline Limestone and dolomite use & - & 0.05 & 0.03 & 0.03 & 0.08 & 0.09 & 0.08 \\
\hline Soda ash & 0.02 & 0.02 & 0.02 & 0.02 & 0.01 & 0.01 & 0.01 \\
\hline Iron and steel production & - & - & 0.55 & 0.41 & 0.28 & 0.28 & 0.28 \\
\hline Ammonia production & 0.49 & 0.40 & 0.21 & 0.18 & 0.19 & 0.22 & 0.24 \\
\hline Urea consumption & 0.01 & 0.01 & 0.01 & 0.01 & 0.01 & 0.02 & 0.02 \\
\hline HFC, PFC, and SF6 emissions & 0.15 & 0.32 & 0.57 & 0.67 & 0.87 & 0.95 & 0.97 \\
\hline ODS substitutes & 0.00 & 0.20 & 0.48 & 0.61 & 0.83 & 0.92 & 0.94 \\
\hline $\begin{array}{l}\text { Electric power transmission } \\
\text { and distribution systems }\end{array}$ & 0.15 & 0.13 & 0.09 & 0.06 & 0.05 & 0.03 & 0.03 \\
\hline
\end{tabular}


Table 2 Inventory of GHG emissions from Nebraska by sector $\left(\mathrm{MMtCO}_{2} \mathrm{e}\right), 1990-2016$ (continued)

\begin{tabular}{|c|c|c|c|c|c|c|c|}
\hline Emissions $\left(\mathrm{MMtCO}_{2} \mathrm{e}\right)$ & 1990 & 1995 & 2000 & 2005 & 2010 & 2015 & 2016 \\
\hline LULUCF & 0.31 & 0.33 & 0.34 & 0.34 & 0.38 & 0.39 & 0.39 \\
\hline Forest fires & - & - & 0.01 & 0.00 & 0.00 & 0.00 & 0.00 \\
\hline $\mathrm{CH}_{4}$ & - & - & 0.01 & 0.00 & 0.00 & 0.00 & 0.00 \\
\hline $\mathrm{N}_{2} \mathrm{O}$ & - & - & 0.00 & 0.00 & 0.00 & 0.00 & 0.00 \\
\hline $\mathrm{N}_{2} \mathrm{O}$ from settlement soils & 0.31 & 0.33 & 0.33 & 0.33 & 0.38 & 0.39 & 0.39 \\
\hline Natural gas T\&D & 2.77 & 1.00 & 1.07 & 4.03 & 3.73 & 3.74 & 4.74 \\
\hline Natural gas & 2.65 & 0.92 & 1.01 & 3.97 & 3.68 & 3.71 & 4.71 \\
\hline Oil & 0.12 & 0.08 & 0.06 & 0.06 & 0.05 & 0.03 & 0.03 \\
\hline Transportation & 11.86 & 12.80 & 13.16 & 13.99 & 15.17 & 15.23 & 15.25 \\
\hline $\mathrm{CO}_{2}$ & 11.36 & 12.20 & 12.59 & 13.60 & 14.93 & 15.08 & 15.10 \\
\hline Gasoline highway & 5.81 & 6.11 & 6.74 & 7.33 & 6.52 & 6.68 & 7.13 \\
\hline Diesel highway & 1.70 & 2.08 & 2.40 & 2.13 & 3.01 & 2.93 & 2.72 \\
\hline Non-highway & 3.85 & 4.01 & 3.44 & 4.12 & 5.39 & 5.46 & 5.24 \\
\hline Alternative fuel vehicles & 0.00 & 0.00 & 0.00 & 0.00 & 0.01 & 0.01 & 0.01 \\
\hline $\mathrm{CH}_{4}$ & 0.06 & 0.06 & 0.05 & 0.04 & 0.03 & 0.03 & 0.03 \\
\hline Gasoline highway & 0.05 & 0.05 & 0.04 & 0.02 & 0.02 & 0.01 & 0.01 \\
\hline Diesel highway & 0.00 & 0.00 & 0.00 & 0.00 & 0.00 & 0.00 & 0.00 \\
\hline Non-highway & 0.01 & 0.01 & 0.01 & 0.01 & 0.01 & 0.01 & 0.01 \\
\hline Alternative fuel vehicles & 0.00 & 0.00 & 0.00 & 0.00 & 0.00 & 0.00 & 0.00 \\
\hline $\mathrm{N}_{2} \mathrm{O}$ & 0.44 & 0.54 & 0.52 & 0.36 & 0.21 & 0.13 & 0.12 \\
\hline Gasoline highway & 0.40 & 0.50 & 0.49 & 0.32 & 0.16 & 0.08 & 0.08 \\
\hline Diesel highway & 0.00 & 0.00 & 0.00 & 0.00 & 0.00 & 0.00 & 0.00 \\
\hline Non-highway & 0.03 & 0.03 & 0.03 & 0.03 & 0.04 & 0.04 & 0.04 \\
\hline Alternative fuel vehicles & 0.00 & 0.00 & 0.00 & 0.00 & 0.00 & 0.00 & 0.00 \\
\hline Waste & 0.86 & 1.01 & 1.19 & 1.37 & 1.60 & 1.65 & 2.66 \\
\hline Solid waste & 0.53 & 0.65 & 0.78 & 0.97 & 1.18 & 1.21 & 2.21 \\
\hline Wastewater & 0.33 & 0.36 & 0.41 & 0.40 & 0.42 & 0.44 & 0.45 \\
\hline Municipal $\mathrm{CH}_{4}$ & 0.13 & 0.13 & 0.14 & 0.14 & 0.15 & 0.15 & 0.15 \\
\hline Municipal $\mathrm{N}_{2} \mathrm{O}$ & 0.05 & 0.05 & 0.05 & 0.05 & 0.05 & 0.06 & 0.06 \\
\hline Industrial $\mathrm{CH}_{4}$ & 0.15 & 0.18 & 0.22 & 0.21 & 0.22 & 0.23 & 0.24 \\
\hline Total gross emissions & 67.20 & 72.84 & 84.31 & 86.03 & 93.51 & 96.69 & 95.77 \\
\hline Carbon stored in LULUCF & -10.95 & -8.16 & -13.46 & -11.11 & -2.91 & -7.67 & -8.35 \\
\hline Forest carbon flux & -6.80 & -4.38 & -4.38 & -9.50 & -1.76 & -1.76 & -1.76 \\
\hline Aboveground biomass & -2.63 & -1.05 & -1.05 & -1.98 & -0.92 & -0.92 & -0.92 \\
\hline Belowground biomass & -0.50 & -0.20 & -0.20 & -0.36 & -0.18 & -0.18 & -0.18 \\
\hline Dead wood & -0.35 & -0.43 & -0.43 & -0.47 & -0.27 & -0.27 & -0.27 \\
\hline Litter & -0.30 & -0.25 & -0.25 & -0.58 & -0.10 & -0.10 & -0.10 \\
\hline Soil organic carbon & -2.59 & -2.31 & -2.31 & -5.96 & -0.15 & -0.15 & -0.15 \\
\hline $\begin{array}{l}\text { Total wood products and } \\
\text { landfills }\end{array}$ & -0.43 & -0.15 & -0.15 & -0.15 & -0.15 & -0.15 & -0.15 \\
\hline Urban trees & -0.11 & -0.12 & -0.13 & -0.14 & -0.15 & -0.16 & -0.16 \\
\hline $\begin{array}{l}\text { Landfilled yard trimmings } \\
\text { and food scraps }\end{array}$ & -0.15 & -0.08 & -0.07 & -0.06 & -0.06 & -0.06 & -0.06 \\
\hline Agricultural soil carbon flux & -3.89 & -3.57 & -8.88 & -1.41 & -0.94 & -5.69 & -6.37 \\
\hline Total net emissions & 56.24 & 64.68 & 70.85 & 74.92 & 90.60 & 89.02 & 87.43 \\
\hline
\end{tabular}

Note: A dash denotes zero attributed emissions or unavailable data, whereas 0.00 denotes values less than 0.005 but greater than zero. 

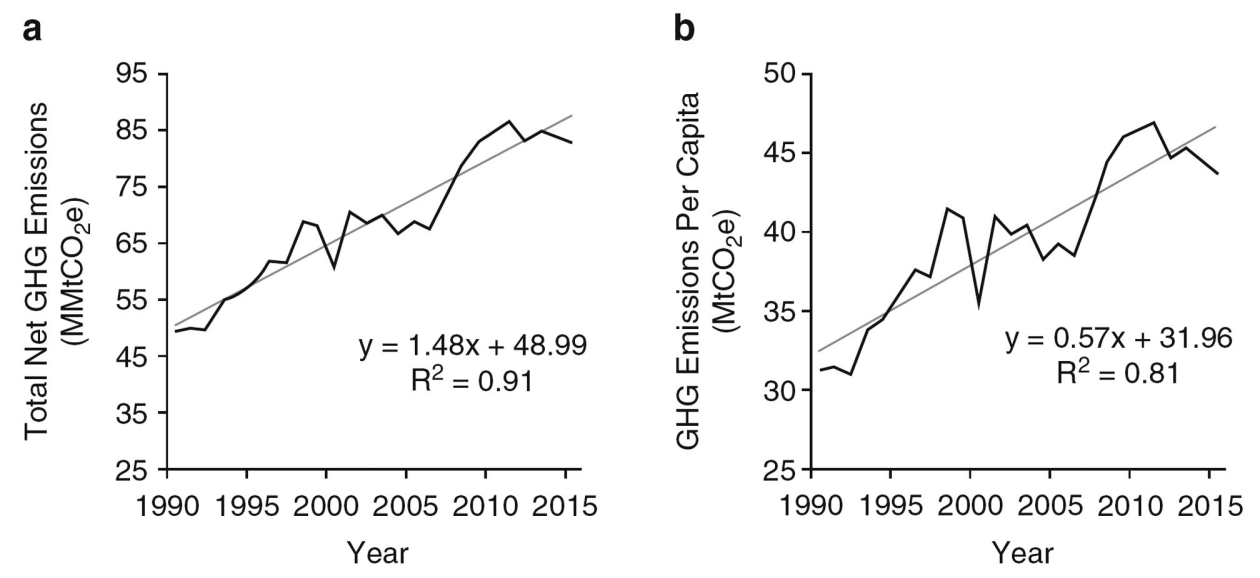

Fig. 1 (a) Total net emissions for Nebraska 1990-2016 $\left(\mathrm{MMtCO}_{2} \mathrm{e}\right)$ and (b) emissions per capita for Nebraska $\left(\mathrm{MtCO}_{2} \mathrm{e}\right), 1990-2015$. Source: Nebraska Energy Office (NEO) (2018a)

625.8, and 87.7 $\mathrm{MMtCO}_{2}$ (EIA 2018a) in 2015, respectively, but didn't include non-energy sectors or GHGs other than carbon dioxide. The largest increase in GHG emissions in Nebraska came between 2000 and 2001 with an increase of $10.35 \mathrm{MMtCO}_{2} \mathrm{e}$. This difference is largely due to an estimated decrease in soil organic carbon under forests (the difference between the release of carbon by oxidation and the storage of carbon through photosynthesis), but these values are uncertain and could simply be the result of a change in methodology. While more carbon was sequestered in later years, this change was offset by increased demands for fossil fuels in electricity production and transportation (Table 2). There were also small increases in emissions produced throughout most industries between 1990 and 2016, probably due to an increase in population size (Table 1) placing higher demands on those industries. The overall trend is an increase of $0.41 \mathrm{MtCO}_{2}$ e per person per year (Fig. 1). Increasing trends for per capita emissions are from emissions growth beyond what can be accounted for by population growth. From 1990 to 2016, significant increases in emissions are primarily from agriculture (increasing by $8.2 \mathrm{MMtCO}_{2} \mathrm{e}$ ) and electricity (increasing by 7.5 MMt$\mathrm{CO}_{2} \mathrm{e}$ ), which accounted for $\sim 50 \%$ of the increase together, with lesser increases in other sectors (Table 2, Fig. 2). 


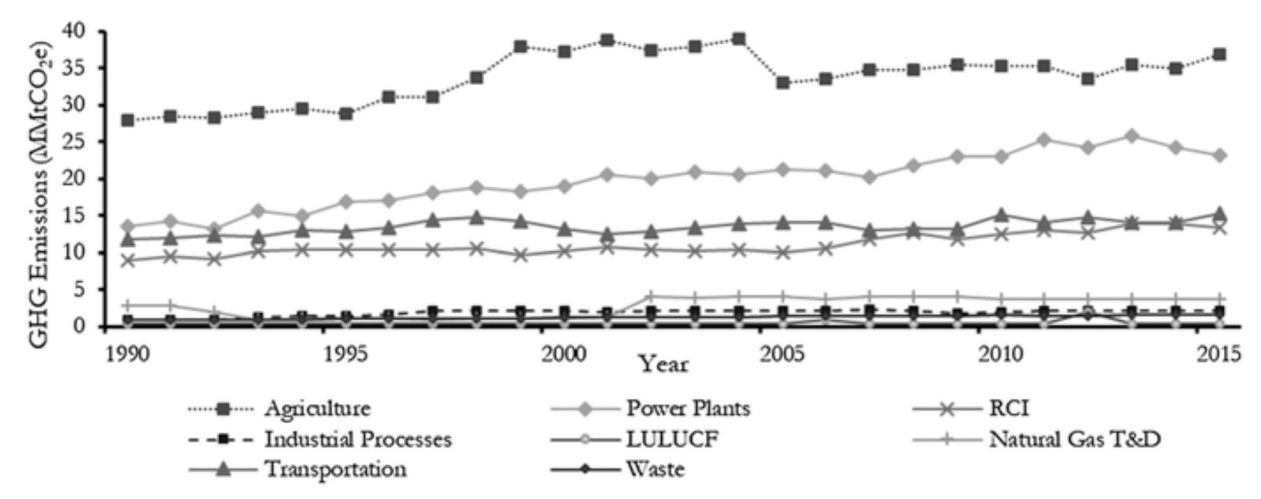

Fig. 2 Nebraska gross GHG emissions by sector $\left(\mathrm{MMtCO}_{2} \mathrm{e}\right), 1990-2016$

\subsection{Emissions of GHGs by Sector}

The majority of emissions between 1990 and 2016 in Nebraska were from the agriculture, electric power, transportation, and RCI sectors (Fig. 2). In 1990, these sectors made up $92.6 \%$ of total emissions (Fig. 3a). By 2016, these sectors decreased slightly to $90.5 \%$ of state emissions (Fig. 3b). The relative proportion of emissions sectors changed from 1990 to 2016, with a much larger share of emissions stemming from energy production and industry compared to agriculture (Fig. 3).

a

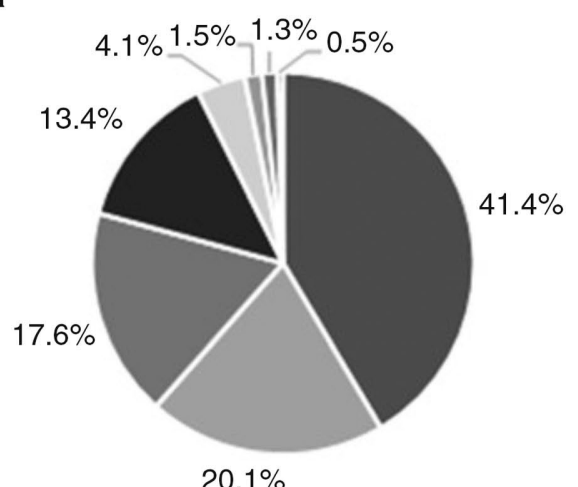

$20.1 \%$ b

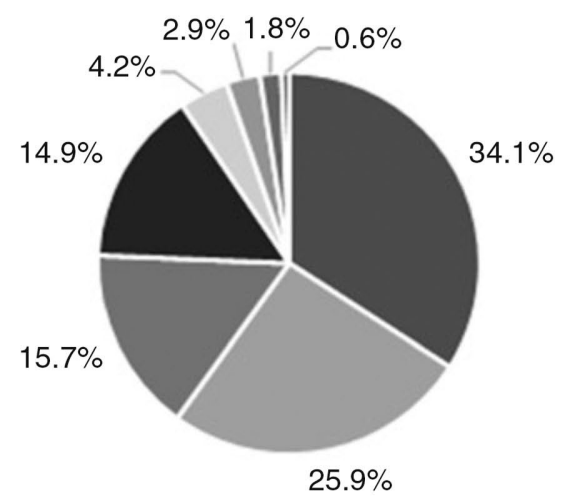

$\begin{array}{ll}\text { - Transportation } & \text { - RCl } \\ \text { - Waste } & \text { - LULUCF }\end{array}$
- Agriculture " Natural Gas T\&D

$$
\begin{aligned}
& \text { = Power Plants } \\
& \text { = Industrial Processes }
\end{aligned}
$$

Fig. 3 Percentage of Nebraska gross GHG emissions by sector: (a) 1990 and (b) 2016 


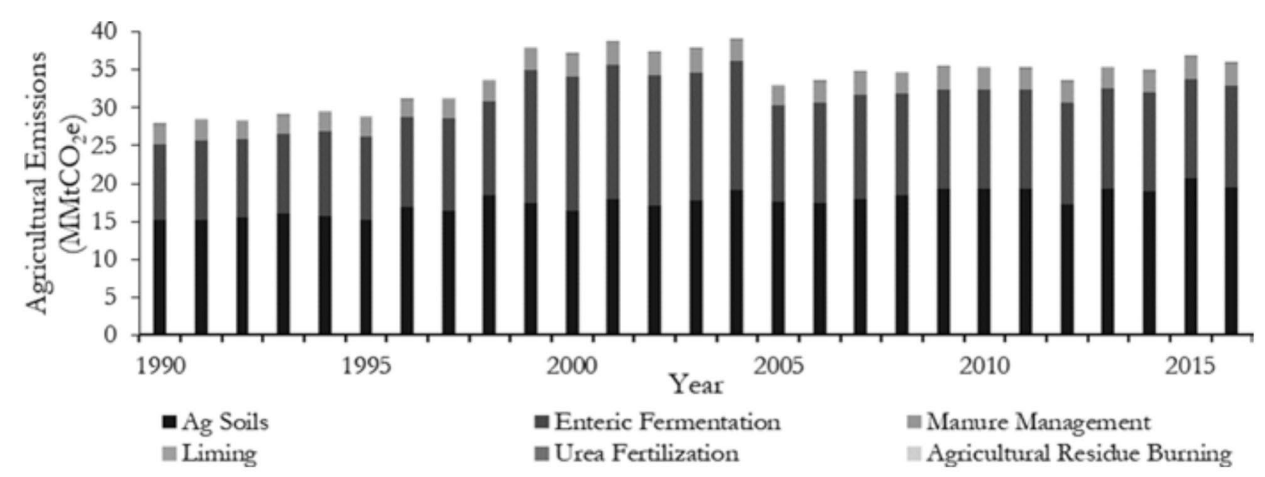

Fig. 4 Nebraska agricultural emissions by category, 1990-2016

\subsubsection{Agriculture}

The agriculture sector is composed of emissions from livestock and crop production through the processes of enteric fermentation, manure management $\left(\mathrm{CH}_{4}\right)$, manure management $\left(\mathrm{N}_{2} \mathrm{O}\right)$, residues and legumes in agricultural soils $\left(\mathrm{N}_{2} \mathrm{O}\right)$, fertilizers on agricultural soils $\left(\mathrm{N}_{2} \mathrm{O}\right)$, animals on agricultural soils $\left(\mathrm{N}_{2} \mathrm{O}\right)$, liming of agricultural soils $\left(\mathrm{CO}_{2}\right)$, and urea fertilization $\left(\mathrm{CO}_{2}\right)$ (Fig. 4). Enteric fermentation emissions are the emissions given off by ruminant animals (including cattle) from their digestive processes. Agricultural soil management includes emissions from fertilizers, runoff, plant residues, and cultivation of highly organic soils. Emissions from field equipment (e.g., tractors, harvesters) are included in the transportation sector. Agricultural emissions increased by nearly $30 \%$ from 1990 to 2016 with a nominal increase of $8.2 \mathrm{MMtCO}_{2} \mathrm{e}$, the second largest increase of all sectors (Table 2 \& Table 3 ).

Table 3 Emissions of GHGs from agriculture $\left(\mathrm{MMtCO}_{2} \mathrm{e}\right)$

\begin{tabular}{lrrrr} 
Category & 1990 & 2016 & Change & \% Change \\
\hline Ag soils & 15.26 & 19.55 & 4.28 & 28 \\
Enteric fermentation & 9.91 & 13.38 & 3.47 & 35 \\
Manure management & 2.55 & 2.90 & 0.35 & 14 \\
Urea fertilization & 0.04 & 0.13 & 0.09 & 219 \\
Liming & 0.08 & 0.04 & -0.04 & -54 \\
Agricultural residue burning & 0.00 & 0.01 & 0.00 & 111 \\
Total & 27.85 & 36.01 & 8.16 & 29 \\
\hline
\end{tabular}




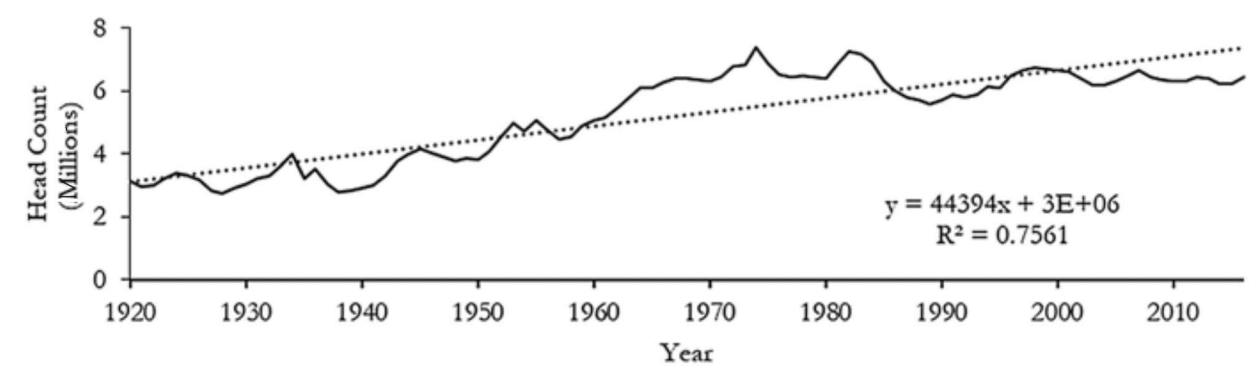

Fig. 5 Total cattle head count in Nebraska, 1920-2016. Source: USDA NASS (2018)

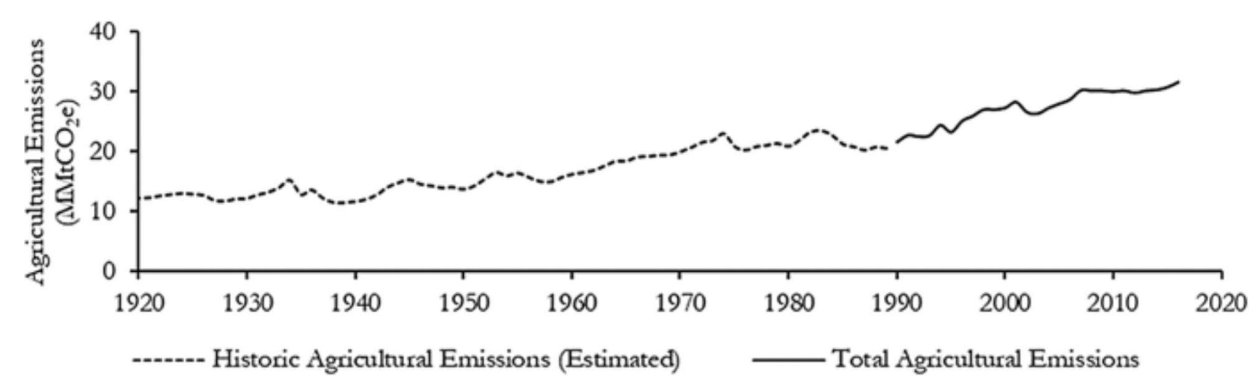

Fig. 6 Estimated historic agricultural GHG emissions (1920-1990) and agricultural emissions (1990-2016)

\section{Historic Agricultural Emissions in Nebraska}

Historic agricultural emissions for Nebraska from 1920 to 1989, based on cattle headcount, were compared to emissions calculated in the GHG inventory from 1990 to 2016 (Figs. 5 \& 6). Cattle head count plateaued after 1970 and has been relatively stable since. Emissions from cattle alone made up, on average, $77.8 \%$ of total agricultural emissions from 1990 to 2016 and $25.8 \%$ of total Nebraska GHG emissions during the same time period. The characteristics and landscape of agriculture changed significantly between 1920 and 2016, and these changes are not accounted for through this method. This approximation of historical agricultural emissions can still give insights into how agriculture has developed over time. 
Table 4 Emissions of GHGs from fossil fuel combustion excluding transportation $\left(\mathrm{MMtCO}_{2} \mathrm{e}\right)$

\begin{tabular}{lrrrr} 
Category & 1990 & 2016 & Change & \% Change \\
\hline Power plants & 13.5 & 21.0 & 7.5 & 55 \\
RCI & 9.0 & 13.5 & 4.4 & 49 \\
Industrial & 4.3 & 9.4 & 5.1 & 117 \\
Residential & 2.5 & 2.2 & -0.3 & -13 \\
Commercial & 2.1 & 1.8 & -0.3 & -15 \\
Total & 22.6 & 34.5 & 11.9 & 53 \\
\hline
\end{tabular}

\subsubsection{Fossil Fuel Combustion}

This sector is composed of GHG emissions from four categories: power plants, residential emissions, commercial emissions, and industrial emissions (Table 4). These last three categories are often labeled under one category, RCI. Combined, these four categories account for $\sim 40 \%$ of total net emissions in 2016. Industrial emissions had the highest increase, largely due to increased natural gas consumption (NEO 2018b). The decrease for the residential and commercial sectors is due to a decrease in direct fuel consumption (i.e., wood or natural gas burned for heating homes or businesses) and probably due to a higher reliance on electric tools, appliances, and other home goods (NEO 2018b).

Emissions from power plants for electricity had the largest increase of any of the sectors in the inventory, followed by agriculture. Emissions from electricity generation come from the increased use of coal, which was $98.4 \%$ of Nebraska's electricity emissions and $23.7 \%$ of Nebraska's net GHG emissions in 2016 (Table 5, Fig. 7). Increases in state emissions

Table 5 Coal-based electricity generation (million MWhrs) and emissions $\left(\mathrm{MMtCO}_{2} \mathrm{e}\right)$ in Nebraska

\begin{tabular}{lrrrr} 
Category & 1990 & 2016 & \multicolumn{2}{r}{ Change \% Change } \\
\hline Coal electricity generation & $12,661,150$ & $21,897,715$ & $9,236,565$ & 73.0 \\
Total electricity generation & $21,633,587$ & $36,524,869$ & $14,891,282$ & 68.8 \\
Percentage coal of total energy Generation & $58.5 \%$ & $60.0 \%$ & 0.01 & 2.4 \\
Coal emissions & 13.3 & 20.7 & 7.4 & 55.3 \\
Total electricity emissions (TEE) & 13.5 & 21.0 & 7.5 & 55.5 \\
Nebraska total net emissions & 56.2 & 87.4 & 31.2 & 55.4 \\
Percentage coal of TEE & $98.5 \%$ & $98.4 \%$ & -0.001 & -0.1 \\
\hline
\end{tabular}

Source: EIA (2018c) 


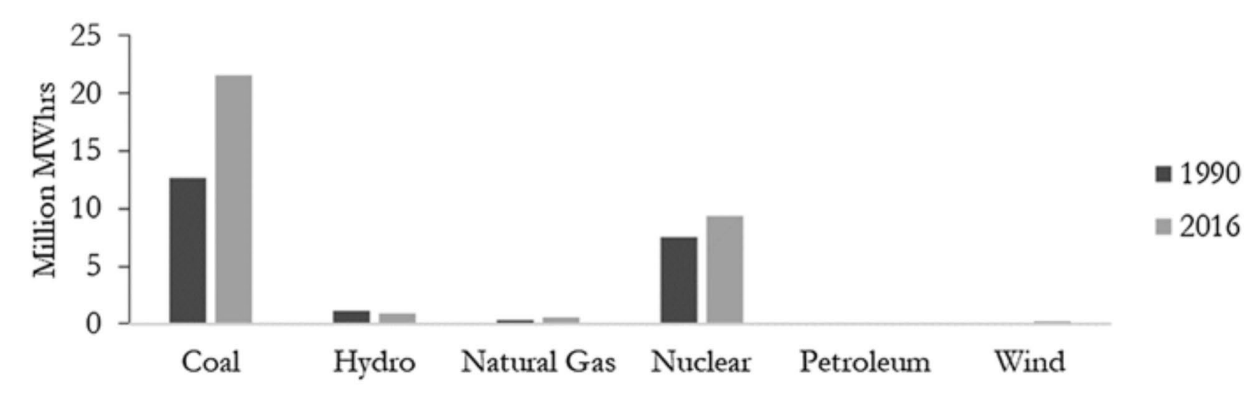

Fig. 7 Nebraska electricity generation by energy source, 1990 and 2016. Source: Energy Information Administration (2018c)

of GHGs have been growing at a steady rate since 1990, increasing by $56 \%$ (Table 1). These steady increases are primarily attributable to increases in electricity generation (Table 2). Electricity consumption in Nebraska has increased by 69\% from 1990 to 2016 (NEO 2019a). The largest increase in electricity use came from industry (146.8\%), compared to the residential (42.2\%) and commercial (44.1\%) sectors. Increased energy demand in Nebraska may be explained by increases in ethanol production in new biorefineries and from transition of pumps for irrigation wells from diesel to electricity, among other factors (Liska and Perrin 2011; NEO 2018b).

\subsubsection{Industrial Processes and Natural Gas Transmission and Distribution}

The industrial processes sector includes non-combustion GHG emissions from a variety of processes including cement production, lime manufacture, limestone and dolomite use, soda ash use, iron and steel production, ammonia production, nitric acid production, substitutes for ozone depleting substances (ODS), and electric power transmission and distribution. Individual categories vary from 1990 to 2016, but the overall trend was an increase by $1.24 \mathrm{MMtCO}_{2} \mathrm{e}$. Industrial processes only account for 1.4\% of total Nebraska emissions for 2016 (Fig. 3). Included in emissions from this sector are natural gas transmission and distribution (T\&D) systems. The increase in T\&D comes from an increase in services and renovations for existing systems (Table 6). 
Table 6 Emissions of GHGs from industrial processes and natural gas transmission and distribution $\left(\mathrm{MMtCO}_{2} \mathrm{e}\right)$

\begin{tabular}{lrrrr} 
Category & 1990 & 2016 & Change & \% Change \\
\hline ODS substitutes & - & 0.94 & 0.94 & - \\
Cement manufacture & 0.32 & 0.52 & 0.20 & 63 \\
Iron and steel production & - & 0.28 & 0.28 & - \\
Ammonia production & 0.49 & 0.24 & -0.25 & -51 \\
Lime manufacture & - & 0.11 & 0.11 & - \\
Limestone and dolomite use & - & 0.08 & 0.08 & - \\
Electric power T\&D systems & 0.15 & 0.03 & -0.12 & -77 \\
Urea consumption & 0.01 & 0.02 & 0.02 & 284 \\
Soda ash & 0.02 & 0.01 & 0.00 & -27 \\
Industrial processes total & 0.99 & 2.23 & 1.24 & 126 \\
Natural gas & 2.65 & 4.71 & 2.06 & 78 \\
Oil & 0.12 & 0.03 & -0.09 & -75 \\
Natural gas T\&D total & 2.77 & 4.74 & 1.97 & 71 \\
\hline
\end{tabular}

\subsubsection{Transportation, Waste, and Land Use, Land Use Change, and} Forestry

Transportation includes both highway and non-highway vehicles in GHG emissions calculations with planes, trains, tractors, boats, utility vehicles, and alternative fuel (biofuels, etc.) counted as non-highway vehicles. Emissions from highway vehicles are calculated based on total vehicle miles traveled and emissions from non- highway vehicles are based on fuel consumption. Increase in locomotive activity accounts for most of the change from 1990 to 2016 alongside a small increase in total miles driven (NEO 2018c) and number of licensed drivers in the state (NEO 2018d). The waste sector incorporates GHG emissions from solid waste landfills and the treatment of municipal and industrial wastewater. Emissions from solid waste increased at a much higher rate than population growth (Table 1), but wastewater emissions increased at a rate more similar to population growth but still higher. These emissions only account for 3.1\% of total Nebraska GHG emissions in 2016. The LULUCF sector accounts for GHG emissions from liming and fertilization of agricultural and residential soils (e.g., golf courses, landscaping) as well as settlement soils. The sector also includes carbon sequestered by forests and urban trees, yard waste, and food scraps in landfills. Negative numbers represent net sequestration (taking in more carbon 
Table 7 Emissions of GHGs from transportation, waste, and LULUCF $\left(\mathrm{MMtCO}_{2} \mathrm{e}\right)$

\begin{tabular}{lrrrr} 
Category & 1990 & 2016 & Change & \% Change \\
\hline Transportation & 11.0 & 15.3 & 3.4 & 29 \\
Solid waste & 0.5 & 2.2 & 1.7 & 314 \\
Wastewater & 0.3 & 0.5 & 0.1 & 36 \\
Waste total & 0.8 & 2.7 & 1.8 & 208 \\
$\mathrm{~N}_{2}$ O from settlement soils & 0.3 & 0.4 & 0.1 & 26 \\
Forest fires & - & 0.002 & 0.002 & - \\
Landfilled yard trimmings and food scraps & -0.1 & -0.1 & 0.1 & -59 \\
Urban trees & -0.1 & -0.2 & 0.0 & 44 \\
Forest carbon flux & -6.8 & -1.8 & 5.0 & -74 \\
Agricultural soil carbon flux & -3.9 & -6.4 & -2.5 & 64 \\
LULUCF total & -10.5 & -8.0 & 2.7 & -25 \\
\hline
\end{tabular}

than giving off through combustion and other processes), and a positive change and percentage change represent less sequestration than previous years (Table 7).

\subsubsection{Emissions of GHGs by Pollutant}

Emissions of GHGs accounted for in the EPA's SIT tool include carbon dioxide $\left(\mathrm{CO}_{2}\right)$, methane $\left(\mathrm{CH}_{4}\right)$, nitrous oxide $\left(\mathrm{N}_{2} \mathrm{O}\right)$, perfluorocarbons (PFC), hydrofluorocarbons (HFC), and sulfur hexafluoride $\left(\mathrm{SF}_{6}\right)$. The LULUCF sector is included in this section to account for the different types of pollutants, but the carbon sinks for LULUCF are not included, so gross emissions are presented in this section rather than net emissions (Table 2). Carbon dioxide is the highest emitted GHG for Nebraska at $60.1 \%$ of total emissions in 1990 and 58\% of total emissions in 2016 (Figs. 8, 9, \& 10). Nearly all $\mathrm{CO}_{2}$ emissions are from combustion or transportation with some coming from industrial processes. A large majority of $\mathrm{CH}_{4}$ and nearly all $\mathrm{N}_{2} \mathrm{O}$ emissions are from the agriculture sector. Natural gas transmission and distribution contributes $\sim 20 \%$ of $\mathrm{CH}_{4}$ emissions with most of the rest coming from waste. A small percentage of $\mathrm{N}_{2} \mathrm{O}$ emissions are from non-agricultural sectors, under $4 \%$ of total $\mathrm{N}_{2} \mathrm{O}$ emissions. The distribution of GHG emissions for Nebraska did not change significantly from 1990 to 2016, but the largest increases came from increased $\mathrm{CO}_{2}$ emissions from electricity and increases in GHG emissions from agriculture. Increases from agriculture were roughly half from $\mathrm{N}_{2} \mathrm{O}$ and half from $\mathrm{CH}_{4}$ (Table 8). 
a

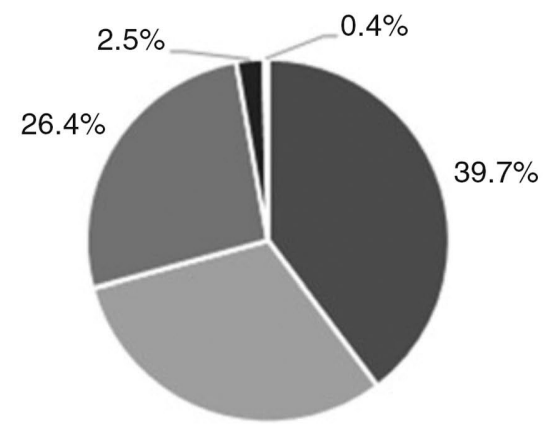

$31.1 \%$ b

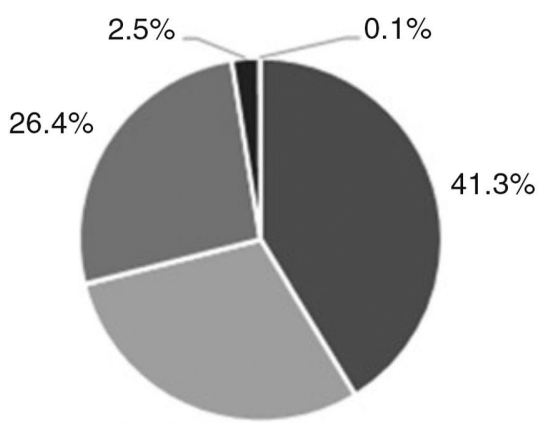

$29.8 \%$

- Power Plants = Transportation = RCl - Industrial Processes = Natural Gas T\&D

Fig. 8 Percentage of carbon dioxide emissions by sector in Nebraska: (a) 1990 and (b) 2016

a

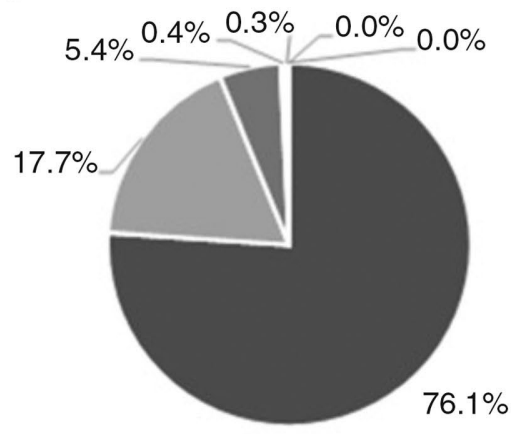

b

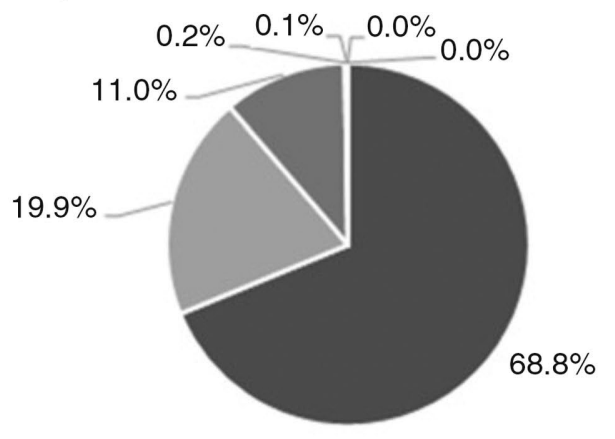

- Agriculture $=$ Natural Gas T\&D $=$ Waste $=$ Transportation $=\mathrm{RCl}$ "Power Plants = LULUCF

Fig. 9 Percentage of methane emissions by sector: (a) 1990 and (b) 2016

a

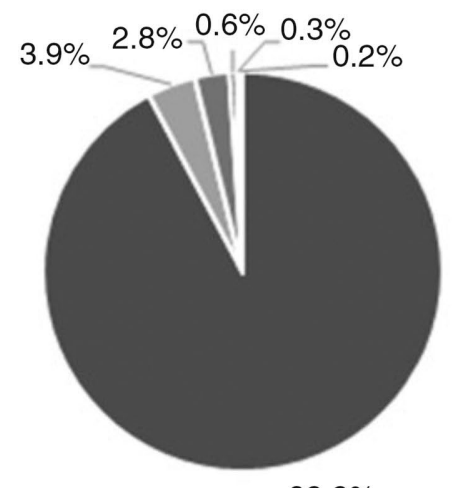

$92.2 \%$ b

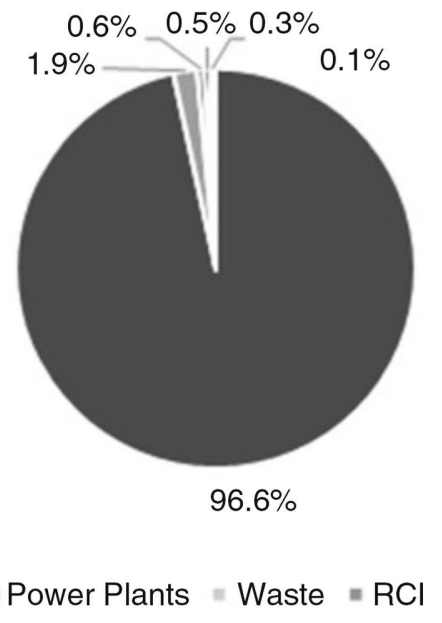

Fig. 10 Percentage of nitrous oxide emissions by sector: (a) 1990 and (b) 2016 
Table 8 Gross emissions of GHGs by pollutant and sector $\left(\mathrm{MMtCO}_{2} \mathrm{e}\right)$

\begin{tabular}{lrrrrrrr} 
GHG and sector $\left(\mathrm{MMtCO}_{2} e\right)$ & 1990 & 1995 & 2000 & 2005 & 2010 & 2015 & 2016 \\
\hline $\mathrm{CO}_{2}$ & 34.9 & 40.8 & 43.5 & 46.3 & 51.4 & 53.0 & 50.9 \\
Power plants & 13.5 & 16.9 & 18.9 & 21.1 & 22.8 & 23.2 & 20.9 \\
Transportation & 11.4 & 12.2 & 12.6 & 13.6 & 14.9 & 15.1 & 15.1 \\
RCI & 9.0 & 10.4 & 10.2 & 10.0 & 12.3 & 13.4 & 13.4 \\
Industrial processes & 0.8 & 1.1 & 1.6 & 1.4 & 1.1 & 1.2 & 1.3 \\
Agriculture & 0.1 & 0.1 & 0.2 & 0.1 & 0.2 & 0.2 & 0.2 \\
Natural gas T\&D & 0.1 & 0.1 & 0.1 & 0.1 & 0.1 & 0.0 & 0.0 \\
CH & 16.0 & 15.6 & 22.9 & 20.7 & 21.1 & 21.3 & 23.7 \\
Agriculture & 12.5 & 13.6 & 15.9 & 15.3 & 15.8 & 15.9 & 16.3 \\
LULUCF & 0.0 & 0.0 & 0.0 & 0.0 & 0.0 & 0.0 & 0.0 \\
Natural gas T\&D & 2.7 & 0.9 & 1.0 & 4.0 & 3.7 & 3.7 & 4.7 \\
Transportation & 0.1 & 0.1 & 0.0 & 0.0 & 0.0 & 0.0 & 0.0 \\
Power plants & 0.0 & 0.0 & 0.0 & 0.0 & 0.0 & 0.0 & 0.0 \\
RCI & 0.0 & 0.0 & 0.0 & 0.0 & 0.0 & 0.0 & 0.0 \\
Waste & 0.8 & 1.0 & 1.1 & 1.3 & 1.5 & 1.6 & 2.6 \\
$\mathrm{~N}_{2} \mathrm{O}$ & 16.1 & 16.3 & 17.5 & 18.5 & 20.3 & 21.6 & 20.4 \\
Agriculture & 15.3 & 15.2 & 16.5 & 17.6 & 19.5 & 20.9 & 19.7 \\
LULUCF & 0.3 & 0.3 & 0.3 & 0.3 & 0.4 & 0.4 & 0.4 \\
Transportation & 0.4 & 0.5 & 0.5 & 0.4 & 0.2 & 0.1 & 0.1 \\
Power plants & 0.1 & 0.1 & 0.1 & 0.1 & 0.1 & 0.1 & 0.1 \\
RCI & 0.0 & 0.0 & 0.0 & 0.0 & 0.0 & 0.0 & 0.0 \\
Waste & 0.1 & 0.1 & 0.1 & 0.1 & 0.1 & 0.1 & 0.1 \\
HFC, PFC, SF & 0.2 & 0.3 & 0.6 & 0.7 & 0.9 & 1.0 & 1.0 \\
Industrial processes & 0.2 & 0.3 & 0.6 & 0.7 & 0.9 & 1.0 & 1.0 \\
Total gross emissions & 73.0 & 84.5 & 86.1 & 93.7 & 96.9 & 95.9 \\
\hline & & & & & & &
\end{tabular}

\section{Comparison of State, US, and Global Emissions}

Nebraska's share of total GHG emissions in the USA increased from $1.05 \%$ in 1990 to $1.46 \%$ in 2016 (Table 9). Yet, Nebraska's portion of the US population decreased slightly from $0.63 \%$ in 1990 to $0.59 \%$ in 2016 in comparison (Table 1). Agricultural emissions account for a significantly higher proportion of Nebraska emissions than US emissions which is consistent with Nebraska's extensive agricultural economy. Emissions from power plants, RCI, natural gas transmission and distribution, and transportation sectors were combined into the energy sector for comparison with US emissions which use the IPCC sectors for the national GHG inventory (IPCC 2006; Fig. 11). Data for US and global emissions comes from the Climate Watch service provided by the World Resources Institute, which only has data to 2014 (Table 10). The US share of global emissions decreased from 1990 to 2014, while Nebraska's share increased during the same time period. 
Table 9 Emissions for Nebraska and the USA by IPCC sector category (MMtCO2e), 1990 and 2016

\begin{tabular}{lrrrr} 
IPCC sector & NE 1990 & U.S. 1990 & NE 2016 & U.S. 2016 \\
\hline Energy & 37.2 & 5339.8 & 54.5 & 5465.3 \\
Agriculture & 27.8 & 490.2 & 36.0 & 541.2 \\
Waste & 0.9 & 198.9 & 2.7 & 131.1 \\
Industrial processes & 1.0 & 342.1 & 2.2 & 354.6 \\
Total & 66.9 & 6371.0 & 95.4 & 6492.2 \\
\hline
\end{tabular}

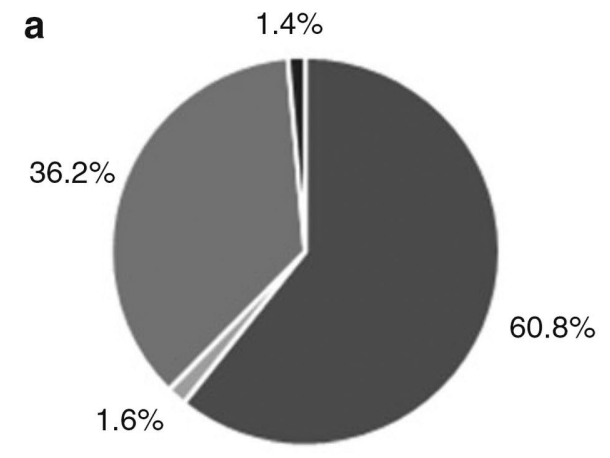

b
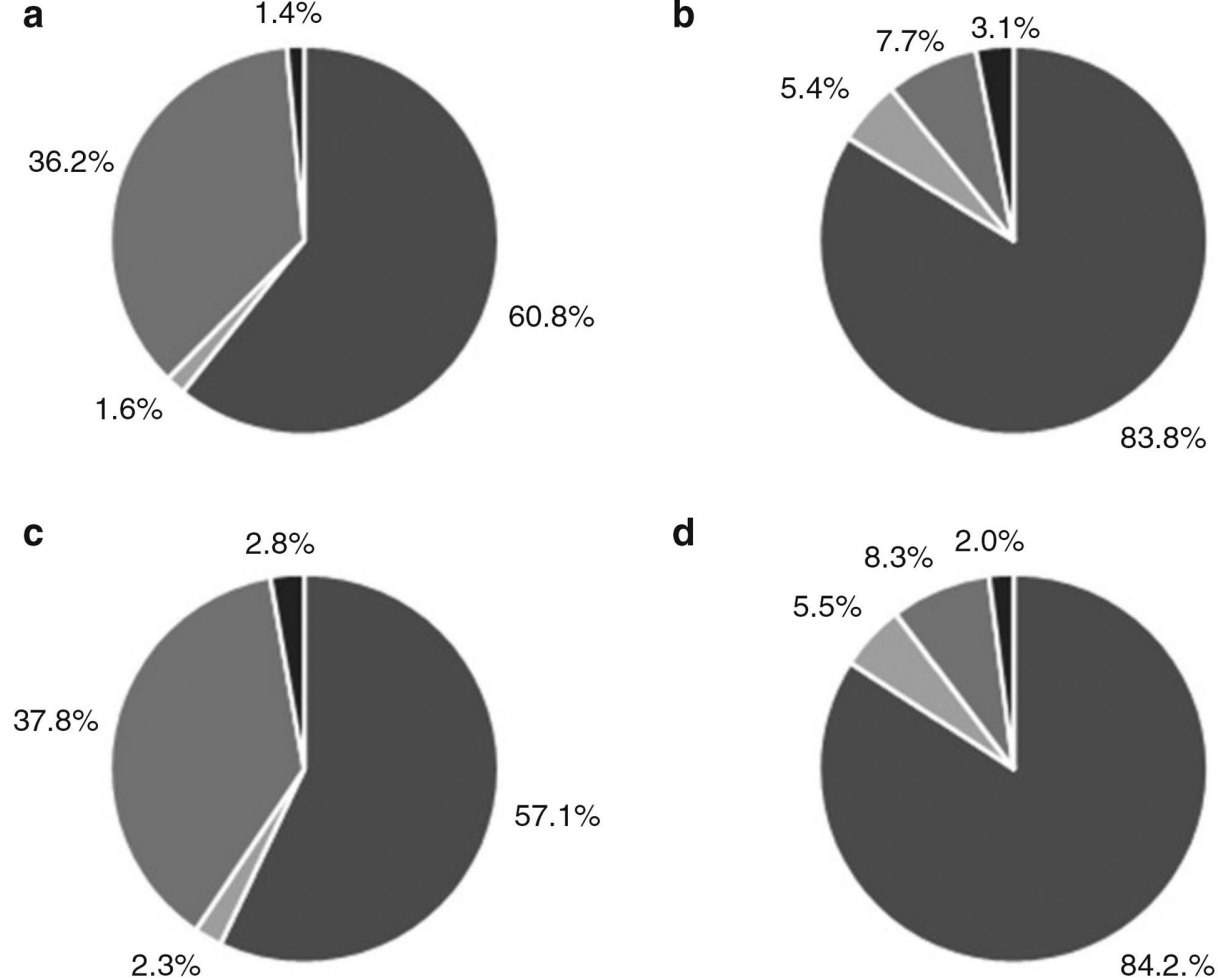

d

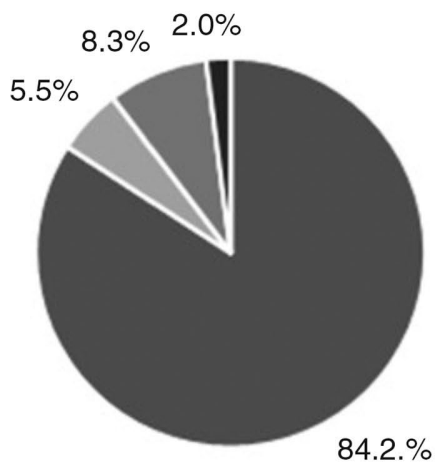

- Energy a Industrial Processes a Agriculture a Waste

Fig. 11 Percentage of GHG emissions by sector: (a) NE 1990, (b) US 1990, (c) NE 2016, (d) US 2016

Table 10 Emissions of GHGs (MMtCO 2 e) by geographic area, 1990 and 2014

\begin{tabular}{lrrrr} 
Category & 1990 & 2014 & Change & \% Change \\
\hline Global & 33,823 & 48,892 & 15,069 & 45 \\
USA & 5564 & 6090 & 526 & 9 \\
Nebraska & 56.2 & 87.9 & 31.7 & 56 \\
Nebraska share of USA & $1.01 \%$ & $1.44 \%$ & 0.004 & 43 \\
US share of global & $16 \%$ & $12 \%$ & -0.04 & -24 \\
Nebraska share of global & $0.2 \%$ & $0.2 \%$ & 0.0001 & 8 \\
\hline
\end{tabular}

Sources: EPA (2019) (U.S.); World Resources Institute (2018) (Global) 
Table 11 Avg. GHG emissions from livestock in Nebraska and Iowa, in 2016 and 2014-2016

\begin{tabular}{lrrrr} 
Category & NE 2016 & IA 2016 & NE 3-year AVG & IA 3-year AVG \\
\hline Gross emissions & 95.8 & 126.6 & 95.8 & 132.5 \\
Net emissions & 87.4 & 126.6 & 88.1 & 132.2 \\
Enteric fermentation & 13.4 & 8.4 & 13.2 & 8.3 \\
Manure management & 2.9 & 11.0 & 2.8 & 10.8 \\
Agricultural soils - Livestock & 4.6 & 2.6 & 5.6 & 2.4 \\
Total agricultural emissions & 36.0 & 39.5 & 35.9 & 38.4 \\
Percent livestock of agricultural soils & $23.5 \%$ & $12.2 \%$ & $28.4 \%$ & $12.2 \%$ \\
Emissions from livestock & 20.9 & 21.8 & 21.6 & 21.5 \\
Percent livestock of gross & $21.8 \%$ & $17.2 \%$ & $22.5 \%$ & $16.2 \%$ \\
Percent livestock of net & $23.9 \%$ & $17.2 \%$ & $24.5 \%$ & $16.2 \%$ \\
Total cattle emissions & 20.7 & 12.7 & 20.5 & 12.5 \\
Percent cattle of gross & $21.6 \%$ & $10.0 \%$ & $21.4 \%$ & $9.4 \%$ \\
Percent cattle of net & $23.7 \%$ & $10.0 \%$ & $23.2 \%$ & $9.4 \%$ \\
Total beef cattle emissions & 19.8 & 10.1 & 19.4 & 9.7 \\
Percent beef cattle of gross & $20.6 \%$ & $7.9 \%$ & $20.3 \%$ & $7.4 \%$ \\
Percent beef cattle of net & $22.6 \%$ & $7.9 \%$ & $22.1 \%$ & $7.4 \%$ \\
\hline
\end{tabular}

Iowa has a higher amount of agricultural emissions compared to $\mathrm{Ne}$ braska, more of Nebraska's emissions come from livestock, specifically cattle, with $23.7 \%$ of net emissions in Nebraska compared to $10 \%$ of net emissions in Iowa (Table 11). Beef cattle were found to contribute $22.6 \%$ of Nebraska's net emissions (Table 11). A larger portion of Iowa's agricultural emissions come from the manure management of swine and poultry, which do not contribute to enteric fermentation. Iowa's swine and poultry populations vastly outnumber Nebraska's populations (USDA NASS 2018) and thus require more manure management. Along with a higher crop output, Iowa's agricultural composition leads to more emissions but also a larger agricultural economy (USDA ERS 2019).

Comprehensive state-level GHG inventories are not common among states in the USA, but some states report gross emissions based on some of the available data for their state. Nebraska has the highest per capita gross emissions based on available data, with Iowa and Texas both higher than US average emissions (Table 12). Nebraska emissions per capita are higher than the other states partly due to having a sparse population with a relatively large geographic area devoted to high- emissions agriculture. Texas's estimated value is not comprehensive and thus underestimates gross GHG emissions as it only accounts for energy-related carbon emissions and cattle emissions. Texas's emissions were estimated by taking energy-related carbon emissions data from the EIA and cattle 
Table 12 Per capita gross GHG emissions for the US and relevant states, 2015a

\begin{tabular}{lrrr} 
State & Gross emissions & Population & Emissions per capita, MtCO $_{2} e$ \\
\hline Nebraska & 89.9 & $1,896,190$ & 47.4 \\
Iowa & 131.8 & $3,123,899$ & 42.2 \\
Texas & $668.9^{\mathrm{b}}$ & $27,469,114$ & 24.4 \\
USA & 6616.8 & $321,418,820$ & 20.6 \\
Vermont & 10.0 & 626,042 & 16.0 \\
Oregon & 63.0 & $4,028,977$ & 15.6 \\
Maine & 19.8 & $1,329,328$ & 14.9 \\
Washington & 97.4 & $7,170,351$ & 13.6 \\
New Jersey & 109.0 & $8,958,013$ & 12.2 \\
California & 441.0 & $39,144,818$ & 11.3 \\
Hawaii & 15.3 & $1,431,603$ & 10.7 \\
\hline
\end{tabular}

a. Several states had not updated to 2016, so 2015 values were used for comparison

b. Estimated value

head count data from the USDA and, assuming the largest sources were also energy and agriculture (specifically cattle), applying the same ratio of cattle head count to emissions in Nebraska to Texas to get an estimated gross emissions value, which may overestimate Texas's cattle emissions (Table 12). Texas is included because it is the largest emitting state in the USA (EIA 2018a). Other states were included primarily due to availability of gross emissions data (DEWA 2018; DECV 2018; DEPM 2019; DEPNJ 2017; DEQO 2018; UHERO and ICF 2019). Nebraska per capita emissions have increased from 38.2 in 1990 to 47.4 in 2015 or $24.1 \%$ over the time frame. Nebraska's 2015 per capita emissions total more than either the US or global averages (Fig. 12).

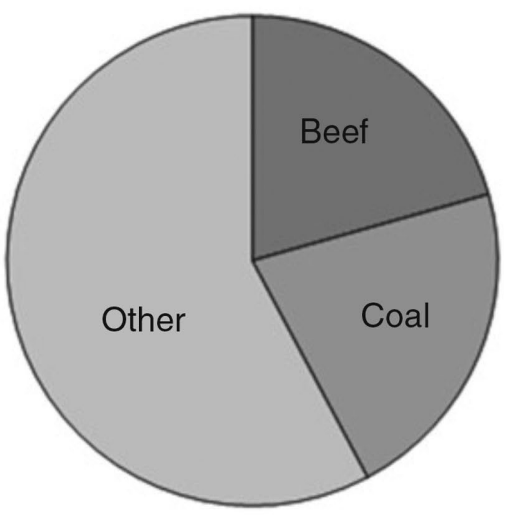

Nebraska - 47

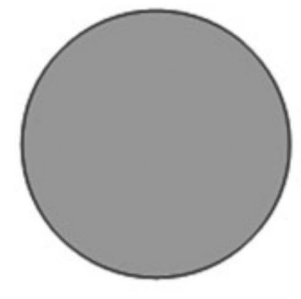

U.S. - 21

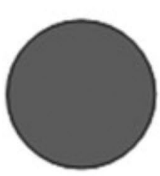

California - 11 Global - 5

Fig. 12 Relative per capita gross GHG emissions (MtCO2e) for selected regions and emissions sources, 2015. Sources: Table 12 (Nebraska, U.S., and California); WRI (2018) (global) 
The states' emissions per capita also do not consider exports of products. In Nebraska, beef production is high but most of that beef is not consumed in the state. Thus, many people argue there exists a "shared responsibility" among states that produce a product and consume that product for the emissions that occur in the transaction between them.

\section{Uncertainties and Limitations to Emissions Estimation}

The accuracy of the EFs calculated by the SIT is the main source of uncertainty for the inventory. EFs are aggregations of measurements, calculations, studies, surveys, and reporting. Even relatively small amounts of uncertainty for each of these elements add to the uncertainty of a given $\mathrm{EF}$, and the calculated EF is quite dependent on the accuracy of the methods that go into estimating it. The mixture of national, regional, and state data also adds some uncertainty to calculations.

The amount of $\mathrm{CH}_{4}$ emissions due to enteric fermentation from livestock is dependent on the accuracy of the animal population estimates and the EFs used for each animal type. Animal populations vary throughout the year, which will affect annual total emissions and is not accounted for by the SIT (ICF 2018). EFs used have inherent uncertainty due to differences in production, environment, diet, and genetics of the animal (ICF 2018). Like enteric fermentation, manure management is subject to uncertainty in livestock populations and EFs. The largest source of uncertainty in manure management, however, comes from EFs of manure management systems. The SIT does not account for Nebraska-specific facilities and relies on regional estimates of emissions for manure management systems. While the SIT does subcategorize animal groups to some extent, there is insufficient data and infrastructure to accurately measure differences in animal types and diet and how they affect the constants used in the SIT (ICF 2004). Nitrogen emissions from soils are dependent on many factors other than nitrogen input, including soil moisture, type, $\mathrm{pH}$, temperature, organic carbon content, oxygen's partial pressure, and soil amendment. The SIT uses only nitrogen input as a factor in calculating $\mathrm{N}_{2} \mathrm{O}$ emissions and does not account for these other variables or their interactions. The combination of type of soil, climate, and management conditions changes nitrogen output, and this highly variable system is simply too complex to accurately determine (ICF 2004). Fertilizer 
usage includes only synthetic fertilizers applied to crops and does not use organic fertilizers (such as manure) due to a lack of Nebraska-specific data for the application of fertilizers.

The fossil fuel consumption section includes GHG emissions from the consumption of fossil fuels in four main categories: power plants, residential, industrial, and commercial (i.e., RCI). The category of power plants includes direct emissions from electricity generation but not indirect emissions from imported electricity. Fossil fuel consumption also does not include fuel combusted from mobile sources. These are included in the "Transportation" section.

The amount of $\mathrm{CO}_{2}$ emitted from fossil fuel consumption depends on the type and amount of fuel that is consumed, the carbon content of the fuel, and the fraction of the fuel that is oxidized. The SIT uses national default values for these variables in calculating emissions, which may differ from Nebraska-specific values. Carbon content and oxidization of fuels are more consistent between states (aside from coal), and the higher variability of coal is accounted for by state in the SIT. Sharing electricity between states adds complexity because it is difficult to track specific fuel mixes for generated or consumed electricity and a regional average is often used. $\mathrm{EFs}$ for $\mathrm{CO}_{2}$ may be generated from relatively uncertain emission monitors rather than carbon content. The amounts of $\mathrm{CH}_{4}$ and $\mathrm{N}_{2} \mathrm{O}$ emitted depend on the amount and type of fuel used, the technology in which it is combusted, and the type of emission control used. The contribution of these emissions to the total GHG emissions is small, however, and estimates are highly uncertain (IPCC 2006; UNEP 2017). Energy consumption and end-use estimates are also uncertain, and some small source emissions may not be included in state-specific or national data (e.g., wood burning in fireplaces, stoves, campfires).

Most of the uncertainty associated with the industrial processes section pertains to the use of national averages and default data within the SIT. State-specific and site-specific data allow for more accurate estimations of GHG emissions. Other sources of uncertainty include inherent uncertainty in geologic composition of raw materials, use of population in calculating emissions, and use of sales rather than consumption in some categories.

The largest sources of uncertainty for transportation are the activity data and the EFs used in calculations. Methods of measurement for VMTs and the application of national factors to state-specific data create 
variability in the total VMTs used. EFs also may not be reflective of conditions in Nebraska. For those parts that use fuel consumption to calculate emissions, it is assumed that all fuel purchased is consumed in the same year.

Emissions of $\mathrm{CH}_{4}$ from landfills are impacted by several factors at individual sites that cannot be accounted for by the SIT. The time period that $\mathrm{CH}_{4}$ is emitted is also uncertain and is affected by the factors listed at the beginning of this section. The amount of $\mathrm{CH}_{4}$ oxidized during diffusion through soil cover over landfills will also affect the net $\mathrm{CH}_{4}$ emissions and is not accounted for by the SIT.

Uncertainty in municipal wastewater is dependent largely on the uncertainty in activity data and EFs. State-specific and site-specific data can reduce this uncertainty to an extent but is still subject to the variation in process and conditions. Uncertainty in industrial wastewater comes from the lack of available data for wastewater outside of red meat production and in the differences between assumed production values and factors on a national scale and site-specific factors for facilities in Nebraska.

There is significant uncertainty in the LULUCF section from the methodologies for EFs and state data. SIT defaults cannot account for the wide variation in tillage practices, landfill composition, fires, and survey methodologies between states. There is inherent uncertainty in estimation methods of land use and land use change as well as geospatial variability. Agricultural soil organic carbon flux has a particularly high associated uncertainty and could affect the values presented in this section significantly. It was included, however, because it tends to overestimate sequestration and underestimate net emissions.

Despite the uncertainties discussed above, the SIT provides a standardized procedure that estimates sector emissions with relatively small errors compared to the absolute amount of emissions and compared to the conclusions that can be interpreted from these sector emissions estimates.

\section{Mitigation of Greenhouse Gas Emissions in Nebraska}

To reduce emissions without reducing consumption, decoupling GHG emissions associated with higher levels of consumption per capita has 
been identified as the paramount engineering challenge of today and the future; emissions could be drastically reduced with combinations of energy-efficient technologies and renewable energy sources available today (Lovins 2013; Pacala and Socolow 2004). Technological changes such as switching from fossil fuels to renewables, reduction in potent GHG emissions, and carbon sequestration could reduce emissions to keep atmospheric warming below a $2{ }^{\circ} \mathrm{C}$ increase by 2100 (Xu and Ramanathan 2017; Millar et al. 2017). Globally, fossil fuel emissions are dominated by electricity and heat, transportation, manufacturing, and construction. Nebraska's annual GHG emissions per capita (47.4 $\mathrm{MtCO}_{2} \mathrm{e}$ ) are more than twice as high as average US emissions per capita (20.6 $\mathrm{MtCO}_{2} \mathrm{e}$ ) and far larger than most regions globally. In 2014, people in the USA and Canada emitted an average of $\sim 16$ metric tons of $\mathrm{CO}_{2}$ per capita per year from fossil fuels, compared to an average of 6.7 metric tons in China, 6 in European countries, 4.5 per capita on average globally, 1.6 in India and other Asian countries, and only 1 metric ton per capita in African countries (IEA 2016). Inclusion of other GHGs, primarily $\mathrm{CH}_{4}$ and $\mathrm{N}_{2} \mathrm{O}$, would increase these emissions but the relative trends would probably remain the same. For example, US emissions were found to be $20.6 \mathrm{MtCO}_{2}$ e per capita where all GHGs were considered, which is slightly higher than the $16 \mathrm{MtCO}_{2}$ per capita per year from fossil fuels alone, as estimated by the IEA. Higher emissions in the USA and Canada are largely due to higher consumption rates but also geographical differences in heating and cooling needs.

Emissions per capita can vary significantly depending on the methods used for estimations. Emissions in the SIT are calculated from production values of products or resources rather than from demand, which is a valid alternative metric. Production values are used, however, because they are often readily available and significantly easier to measure than demand (consumption). Areas with high production but low demand (large amounts of exports of a product) will have higher emissions per capita values than those based on consumption in an area. For Nebraska, per capita emissions based on consumption could be significantly lower than the values presented above (Table 12), as most of the beef produced in the state is exported rather than consumed by the population. Per capita production emissions can be interpreted as state activity that is attributed to the population in that state, as that population is ultimately responsible for the economy and laws that facilitate those 
emissions. Thus, the production-based per capita GHG emissions values for Nebraska presented above should accurately represent the population's impact on climate change.

A GHG emissions inventory for Nebraska is an important and feasible endeavor to track emissions to provide a framework for evaluating state-specific solutions and inform climate change mitigation decisions. Nebraska's GHG emissions and its share of national GHG emissions have steadily increased since 1990 (Table 10). Emissions growth has outpaced population growth, meaning Nebraska emits more per person in 2016 than in 1990 (Table 1). The distribution of Nebraska's GHG emissions are much different compared to the national level, with over $37 \%$ of emissions from agriculture compared to $8 \%$ nationally (Fig. 11). Agriculture and electricity were found to be the two highest emissions sectors in Nebraska (Table 2) and thus require the greatest attention to significantly reduce state emissions in the near term.

The largest category of agricultural GHG emissions in Nebraska is from beef cattle, where feedlots are a major contributor with a population of $\sim 2.7$ million head in 2016 (Fig. 13). Where agricultural emissions reductions are sought, the most direct action would be to reduce the population of beef cattle in the state. The IPCC recently suggested that changes in diet, including reduced meat consumption and increased use of agricultural products from resilient, sustainable, lowGHG emission systems, have a high potential for GHG emissions mitigation and improvement of human health globally (IPCC 2019). But such a reduction in beef cattle will not be easily achieved as the livestock industry in Nebraska had annual sales of roughly $\$ 11.7$ billion dollars in

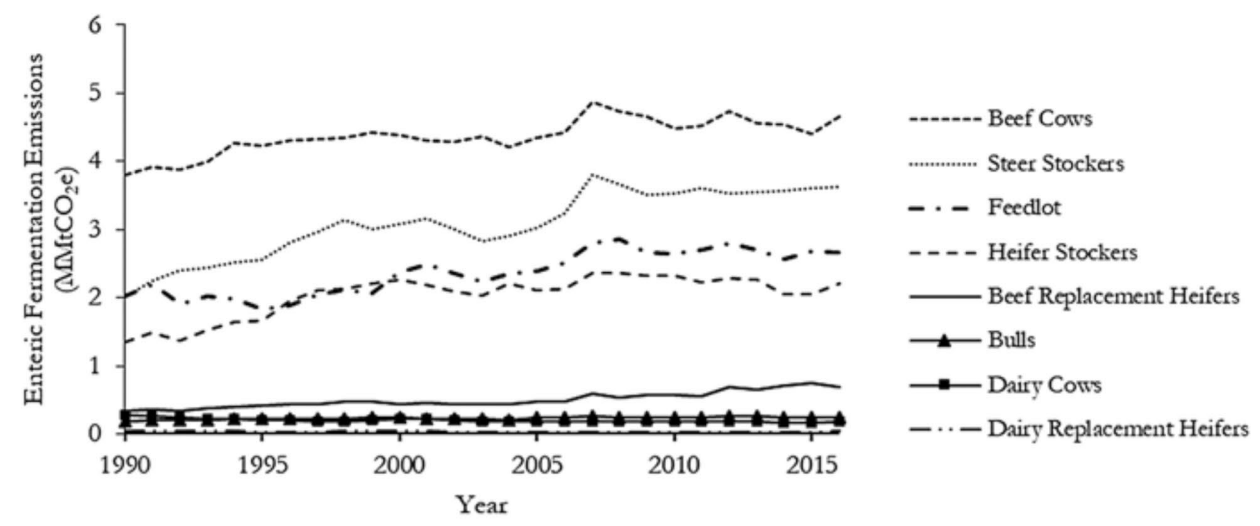

Fig. 13 Enteric fermentation emissions by cattle category, 1990-2016 
2012 (USDA NASS 2019), which means there are extensive social, economic, and political interests that may complicate such reductions. One potential and perhaps equitable solution to reduce livestock populations would come from a carbon tax on the consumption of beef and other animal products. A carbon tax of $\$ 248$ per ton of $\mathrm{CO}_{2} \mathrm{e}$ could increase the price of beef by as much as $41 \%$ in the supermarket, which reflects the external costs of climate change (Coniff 2018). Current carbon prices are as high as $\$ 139$ per ton of $\mathrm{CO}_{2} \mathrm{e}$ in Sweden and $\$ 101$ in Switzerland and Liechtenstein, but most plans propose to price carbon at $\$ 55$ per ton of $\mathrm{CO}_{2} \mathrm{e}$ or lower (World Bank and Ecofys 2018). An increase in the price of beef would probably lower demand, and consumers would probably substitute some of the beef they consume for lowercost options such as pork, poultry, or plant-based proteins. Plant-based protein companies have already invested in manufacturing alternative meat products in the state and are expected to add value to the agricultural industry (Lee 2018).

As monogastric animals, pork and poultry are considerably less GHGintensive compared to beef. Based on life cycle assessments of meat production, emissions from pork are $\sim 21 \%$ of those from beef and poultry are $\sim 18 \%$ (Fig. 14). The production of pork and poultry also requires less water, is associated with less nitrogen pollution, and requires less land area (Fig. 14). Substitutions away from beef could cause state-level reductions in GHG emissions. If all beef $\left(9.6 \mathrm{~kg} \mathrm{CO}_{2} \mathrm{e} / \mathrm{Mcal}\right)$ were substituted with pork (2.03 $\left.\mathrm{kg} \mathrm{CO}_{2} \mathrm{e} / \mathrm{Mcal}\right)$, Nebraska emissions would be lowered by $15.64 \mathrm{MMtCO}_{2} \mathrm{e}$ based on emissions per unit energy in meat (Fig. 14) or 17.9\% of Nebraska's net emissions in 2016.

Actions that reduce agricultural emissions without reducing livestock populations are also viable and can be used in conjunction with reduction of consumption of livestock. There is a significant amount of variance among farms due to agricultural practices, geography, temperature, and many other factors (Poore and Nemecek 2019). Solutions to address these emissions (e.g., multivariate, ground-up approach to quantify impacts; setting and incentivizing mitigation targets; reducing impacts through choices upstream in the supply chain; dietary changes; food supply and waste changes; communication and cooperation between entities in the supply chain to reduce impacts) are as varied as the factors themselves and the complexity is such that a potential solution addressing the same product in similar conditions across multiple farms 
A)

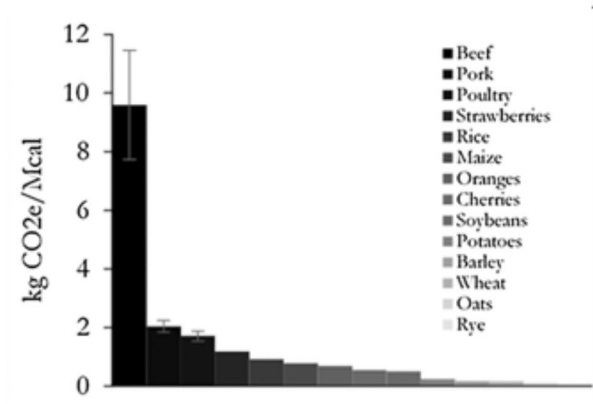

B)

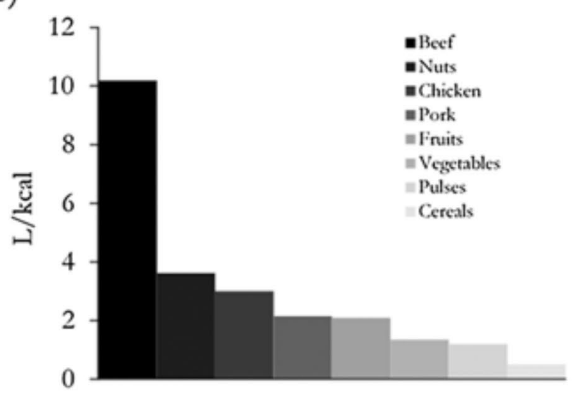

C)

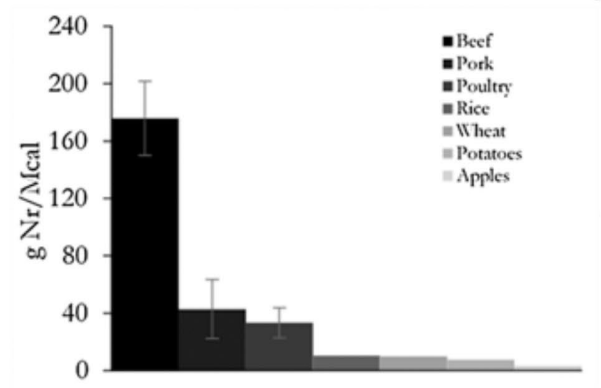

D)

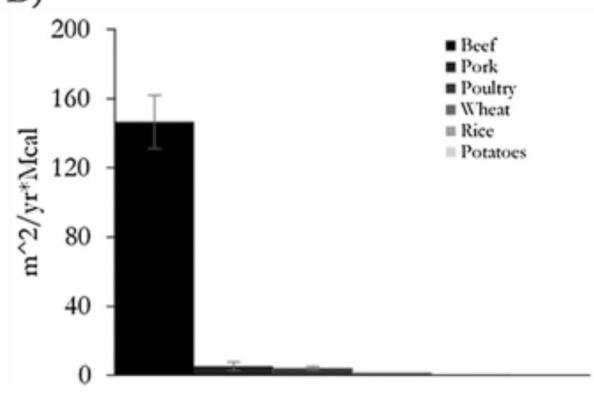

Fig. 14 Environmental impacts of livestock and common food crops in the USA (A, C, and D) and globally (B). (a) Greenhouse gas emissions (González et al. 2011; Eshel et al. 2014); (b) total water use (Hoekstra and Mekonnen 2012); (c) reactive nitrogen use; (d) arable land use (Eshel et al. 2014). Note: Environmental impacts of beef, pork, and poultry include results from other life cycle assessments compiled by Eshel et al. (2014) including de Vries and de Boer (2010); Phetteplace et al. (2001); and Pelletier (2008, Pelletier et al. 2010a, b). Thus, they are plotted as averages with standard deviations here.

may not be effective for all of those farms. With proper localized data and analysis, however, a portfolio of solutions can greatly reduce variability and lower emissions for producers of agricultural products (Poore and Nemecek 2019). For example, dietary changes in beef cattle, such as inclusion of more fats in feeds, can significantly reduce enteric fermentation emissions which are relevant for Nebraska agriculture (Beauchemin and McGinn 2008). A multivariate approach could reduce environmental impacts and allow policymakers and producers more options in how they address agricultural emissions (Pacala and Socolow 2004). Conversion of grasslands to agricultural land could also significantly contribute to emissions in Nebraska. From 2006 to 2011, expansion of maize 
area in the central USA resulted in 530,000 hectares converted from grassland to row crops (Wright and Wimberly 2013), which is associated with extensive carbon emissions from the disruption of soils (Fargione et al. 2008). In Nebraska, from 2006 to 2012, 250,000 hectares of grassland were converted to cropland with another 110,000 from 2014 to 2016 (Joshi et al. 2019). Increasing ethanol production and demand increase crop prices, which correspondingly drives conversion of grasslands to maize; the ethanol industry in Nebraska consumes $\sim 40 \%$ of the state's annual production of maize. Cropland can be converted back to grassland, but this is unlikely to occur unless ethanol demand and maize prices are also reduced, or relevant policy is implemented. Reduced demand for grain could cause a corresponding reduction in the acreage of maize, with corresponding reductions in nitrogen use and land conversion and thus reductions in GHG emissions.

The second largest sector of emissions in Nebraska comes from electricity generation (Table 2). Reducing GHG emissions from electricity, like many other mitigation scenarios, will require a portfolio of solutions (Pacala and Socolow 2004). There are several strategies that can be used to reduce emissions from electricity including reducing demand, changing fuel sources, and increasing the efficiency of the electrical system. Reducing electricity demand can be done through increasing efficiency of electric devices (e.g., LED lighting, appliances, phones, electric cars) or by using less energy intensive processes for manufacturing or in the home, such as turning the lights off when not in use, as well as differential pricing or other policies. The most direct way to reduce emissions from electricity use is to change fuel sources for electric plants from fossil fuels to zero or net-zero emissions sources such as nuclear, solar, or wind (Tollefson 2018). Changing fuel sources requires investment in new infrastructure among other issues (Davis et al., 2018), but integration of these sources into existing structures is already occurring, and decreasing prices for these alternative energy sources makes incorporation increasingly feasible (Tollefson 2018). Lastly, increasing the efficiency of Nebraska's electric infrastructure and reducing electrical waste can reduce emissions. Nearly $5 \%$ of electricity T\&D is lost annually in the USA (EIA 2019b).

The incorporation of external costs from climate change into fossil fuels can help put into perspective the actual costs of fossil fuels compared to zero or net-zero emissions sources. Coal currently costs the 
second least per kilowatt-hour in Nebraska for direct fuel costs $(\$ 0.60$ more than nuclear per million BTUs; NEO 2019b), but if the costs of carbon emissions were included in the cost of electricity, the higher price of coal would probably be less competitive compared to the initial infrastructure costs of renewable and/or net-zero GHG emissions sources. A carbon tax, much as with livestock, is a potential way to quantify these external costs. Tax breaks, subsidies, and other incentives can also be used to increase the use of zero or net-zero emission energy sources; unlike most states, Nebraska currently does not have a renewable portfolio standard, energy efficiency resource standards, or energy efficiency resource goals (DSIRE 2019). Potential solutions will need to consider the effect that they might have economically and related repercussions. While a change might reduce emissions in the short term (probably by reducing consumption), production or use may simply shift elsewhere and increase net emissions.

Carbon taxes or cap-and-trade systems are an indispensable strategy for the reduction of GHG emissions efficiently across sectors (HLCCP 2017). While the two largest emissions sectors in Nebraska are agriculture and energy, carbon pricing should be applied to all sectors. Carbon pricing is used internationally, nationally, regionally, and subnationally to help reach environmental and social objectives (HLCCP 2017; World Bank and Ecofys 2018). Revenue generated from a carbon tax can be redistributed back to citizens on a per capita basis (a "climate dividend"), which could limit government holdings of climate revenue and keep average tax burdens largely unchanged (Carattini et al. 2019). Most people, however, tend to overestimate the costs of carbon pricing and underestimate its benefits which can impede implementation of carbon prices (Carratini et al. 2018). Yet, research has shown that once a carbon price is enacted, public support has increased over time. Ultimately, there will be no single solution for significant GHG emissions reductions. A diverse set of technologies and policies will be essential for meeting adaptation and mitigation goals (Pacala and Socolow 2004; HLCCP 2017; World Bank and Ecofys 2018). Furthermore, to avoid some of the worst impacts of a rapidly changing climate, action will need to be taken sooner rather than later (Figueres et al. 2017; IPCC 2006; Tollefson 2018). 


\section{Conclusion}

The first step toward reducing Nebraska's contribution to climate change is understanding the state of emissions today. A comprehensive GHG emissions inventory is necessary to understand where mitigation efforts could have the greatest impact, and future inventories will allow maintenance and adjustment of these strategies as needed. Agriculture and electric power were found to be the two largest sectors of emissions for Nebraska, and any plans to reduce GHG emissions should prioritize these categories, with attention to beef cattle and coal. Nebraska may yet be an important example for the USA and the world that significant reductions of GHG emissions are possible, if the state's population accepts its responsibility to address climate change and acts accordingly.

Acknowledgments The authors thank Katie Torpy, Calvin Harman, Richard Perrin, Rick Stowell, David Aiken, Michael Hayes, Joe Stansberry, and Marnie Stein.

\section{References}

Beauchemin KA, McGinn SM (2008) Reducing methane in dairy and beef cattle operations: what is feasible. Prairie Soil Crop 1:17-21

Carattini S, Carvalho M, Fankhauser S (2018) Overcoming public resistance to carbon taxes. Wiley Interdiscip Rev Clim Change 9(5):e531

Carattini S, Kallbekken S, Orlov A (2019) How to win public support for a global carbon tax. Nature 565:289-291

Coniff R (2018) The case for a carbon tax on beef. The New York Times. March 17

Database of State Incentives for Renewables \& Efficiency (DSIRE) (2019) Detailed summary maps

Davis SJ, Lewis NS, Shaner M, Aggarwal S, Arent D, Azevedo IL et al (2018) Net-zero emissions energy systems. Science 360(6396)

de Vries M, de Boer IJ (2010) Comparing environmental impacts for livestock products: a review of life cycle assessments. Livestock Sci 128(1-3):1-11

Department of Ecology State of Washington (DEWA) (2018) Washington state greenhouse gas emissions inventory: 1990-2015 report to the legislature. Lacey, WA

Department of Environmental Conservation Air Quality and Climate Division State of Vermont (DECV) (2018) Greenhouse gas emissions inventory update: brief 19902015. Montpelier, VT 
Department of Environmental Protection State of Maine (DEPM) (2019) Reducing greenhouse gas emissions. Augusta, ME

Department of Environmental Protection State of New Jersey (DEPNJ) (2017) 2015 statewide greenhouse gas emissions inventory. Trenton, NJ

Department of Environmental Quality State of Oregon (DEQ0) (2018) Oregon's greenhouse gas emissions: 1990-2016 prepared for the Oregon office of carbon policy. Portland, OR

Department of Transportation (DOT) (2018) Distribution, transmission, and liquid annual data 1990-2016. Washington, DC

EIA (2014) Annual energy outlook 2014: implications of low electricity demand growth. Washington, DC

EIA (2018a) Detailed state electricity data. Washington, DC

EIA (2018b) Nebraska state profile and energy estimates. Washington, DC

EIA (2018c) Detailed state data. Washington, DC

EIA (2019a) Petroleum sales and consumption: fuel oil and kerosene sales. Washington, DC

EIA (2019b) How much electricity is lost in electricity transmissions and distribution in the United States? Washington, DC

EPA (2019) Inventory of U.S. Greenhouse gas emissions and sinks: 1990-2017. Washington, DC

Eshel G, Shepon A, Makov T, Milo R (2014) Land, irrigation water, greenhouse gas, and reactive nitrogen burdens of meat, eggs, and dairy production in the United States. Proceedings of the National Academy of Sciences 111(33):11996-12001

Fargione J, Hill J, Tilman D, Polasky S, Hawthorne P (2008) Land clearing and the biofuel carbon debt. Science 319(5867):1235-1238

Federal Highway Administration (FHWA) (2019) Highway statistics series. Washington, DC

Figueres C, Schellnhuber HJ, Rockstrom J, Hobley A, Rahmstorf S (2017) Three years to safeguard our climate. Nature 546:593-595

Gerber PJ, Steinfeld H, Henderson B, Mottet A, Opio C, Dijkman J et al (2013) Tackling climate change through Livestock - a global assessment of emissions and mitigation opportunities. Food and Agriculture Organization of the United Nations (FAO), Rome

González AD, Frostell B, Carlsson-Kanyama A (2011) Protein efficiency per unit energy and per unit greenhouse gas emissions: potential contribution of diet choices to climate change mitigation. Food Policy 36(5):562-570

Hansen J, Sato M, Kharecha P, Von Schuckmann K, Beerling DJ, Cao J et al (2017) Young people's burden: requirement of negative $\mathrm{CO}_{2}$ emissions. Earth Syst Dyn 8:577-616

High-Level Commission on Carbon Prices (HLCCP) (2017) Report of the high-level commission on carbon prices. World Bank, Washington, DC

Hoekstra AY, Mekonnen MM (2012) The water footprint of humanity. Proc Natl Acad Sci 109(9):3232-3237 
ICF (2018) 2015 Chicago regional greenhouse gas emissions inventory. Fairfax, VA

ICF Consulting (2004). Emissions Inventory Improvement Program (EIIP) Volume VIII: greenhouse gases. Prepared for the U.S. Environmental Protection and STAPPA/ALAPCO, Washington DC.

IEA (2016) CO2 emissions from fuel combustion. Paris, France

Iowa Department of Natural Resources (DNR) (2018) 2017 Iowa statewide greenhouse gas emissions inventory report. Des Moines, IA

IPCC (2006) 2006 IPCC Guidelines for National Greenhouse Gas Inventories. The National Greenhouse Gas Inventories Programme, The Intergovernmental Panel on Climate Change (eds. Eggleston HS, Buendia L, Miwa K, Ngara T, Tanabe K). Hayama, Kanagawa, Japan

IPCC (2019) Climate Change and Land: an IPCC special report on climate change, desertification, land degradation, sustainable land management, food security, and greenhouse gas fluxes in terrestrial ecosystems. Geneva, Switzerland

Joshi DR, Ulrich-Schad J, Wang T, Dunn BH, Clay SA, Bruggeman SA, Clay DE (2019) Grassland retention in the North America Midwest after periods of high commodity prices and climate variability. Soil Sci Soc Am J 83(5):1290-1298

Lee J (2018) Ingredion to spend millions of dollars on plant-based South Sioux City plant. Sioux City Journal, Sioux City, IA.

Liska AJ, Perrin RK (2011) Energy and climate implications for agricultural nutrient use efficiency. In: Clay DE, Shanahan JF (eds) GIS applications in agriculture, volume two: nutrient management for energy efficiency. CRC Press, Boca Raton, pp 1-17

Lovins A (2013) Reinventing re: bold business solutions for the new energy era. Chelsea Green Publishing, Hartford, VT

Millar RJ, Fuglestvedt JS, Friedlingstein P, Grubb M, Rogelj J, Matthews HD et al (2017) Emission budgets and pathways consistent with limiting warming to $1.5^{\circ} \mathrm{C}$. Nat Geosci 10:741-747

Morton O (2016) The planet remade: how geoengineering could change the world. Princeton University Press, Princeton, NJ

NDA (2019) Nebraska agriculture fact card. Lincoln, NE

NEO (2018a) Population by age, Nebraska. Lincoln, NE

NEO (2018b) Annual report 2017. Lincoln, NE

NEO (2018c) Motor vehicle miles traveled in Nebraska. Lincoln, NE

NEO (2018d) Nebraska motor vehicle registrations. Lincoln, NE

NEO (2019a) Electricity consumption in Nebraska by end-use sector. Lincoln, NE

NEO (2019b) Energy prices in Nebraska's electric power sector. Lincoln, NE

Pacala S, Socolow R (2004) Stabilization wedges: solving the climate problem for the next 50 years with current technologies. Science 305(5686):968-972

Pelletier N (2008) Environmental performance in the US broiler poultry sector: life cycle energy use and greenhouse gas, ozone depleting, acidifying and eutrophying emissions. Agric Syst 98(2):67-73 
Pelletier N, Pirog R, Rasmussen R (2010a) Comparative life cycle environmental impacts of three beef production strategies in the Upper Midwestern United States. Agric Syst 103(6):380-389

Pelletier N, Lammers P, Stender D, Pirog R (2010b) Life cycle assessment of high-and low-profitability commodity and deep-bedded niche swine production systems in the Upper Midwestern United States. Agric Syst 103(9):599-608

Phetteplace HW, Johnson DE, Seidl AF (2001) Greenhouse gas emissions from simulated beef and dairy livestock systems in the United States. Nutr Cycling Agroecosyst 60(1):99-102

Poore J, Nemecek T (2019) Reducing food's environmental impacts through producers and consumers. Science 360(6392):987-992

Tollefson J (2018) Can the world kick its fossil-fuel addiction fast enough? Nature 556:422-425

United Nations Environmental Program (UNEP) (2017) The Emissions Gap Report 2017. Nairobi, Kenya

United Nations Population Division (UNPD) (2018) World population prospects 2017. New York, NY.

United States Census Bureau (2018) 2018 population estimates. Washington, DC

United States Global Climate Research Program (USGCRP) (2018) Impacts, risks, and adaptation in the united states: fourth national climate assessment, Volume II (eds. Reidmiller DR, Avery CW, Easterling DR, Kunkel KE, Lewis KLM, Maycock TK, Stewart BC). US Global Change Research Program, Washington, DC, 1515 pp

University of Hawaii Economic Research Organization (UHERO) and ICF (2019) Hawaii greenhouse gas emissions report for 2015. Fairfax, VA

USDA ERS (2012) Irrigation \& water use. Washington, DC

USDA ERS (2019) Cash receipts by commodity. Washington, DC

USDA NASS (2019) 2018 State agriculture overview: Nebraska. Washington, DC

USDA National Agricultural Statistics Service (NASS) (2018) Quick stats. Washington, DC

World Bank and Ecofys (2018) State and trends of carbon pricing 2018 (May), by World Bank, Washington, DC

World Resources Institute (2018) Climate watch. Washington, D.C.

Wright CK, Wimberly MC (2013) Recent land use change in the Western Corn Belt threatens grasslands and wetlands. Proc Natl Acad Sci 110(10):4134-4413

Xu Y, Ramanathan V (2017) Well below $2^{\circ} \mathrm{C}$ : mitigation strategies for avoiding dangerous to catastrophic climate changes. Proc Natl Acad Sci 114:10315-10323

Yumashev D, Hope C, Schaefer K, Riemann-Campe K, Iglesias-Suarez F, Jafarov E et al (2019) Climate policy implications of nonlinear decline of Arctic land permafrost and sea ice. Nat Commun 10(1900) 